Portland State University

PDXScholar

\title{
The Earliest American Map of the Northwest Coast: John Hoskins's A Chart of the Northwest Coast of America Sketched on Board the Ship Columbia Rediviva ... 1791 \& 1792
}

James V. Walker

William L. Lang

Portland State University, langw@pdx.edu

Follow this and additional works at: https://pdxscholar.library.pdx.edu/hist_fac

Part of the United States History Commons

Let us know how access to this document benefits you.

\section{Citation Details}

Walker, James V. and Lang, William L., "The Earliest American Map of the Northwest Coast: John Hoskins's A Chart of the Northwest Coast of America Sketched on Board the Ship Columbia Rediviva ... 1791 \& 1792" (2017). History Faculty Publications and Presentations. 36.

https://pdxscholar.library.pdx.edu/hist_fac/36

This Article is brought to you for free and open access. It has been accepted for inclusion in History Faculty Publications and Presentations by an authorized administrator of PDXScholar. Please contact us if we can make this document more accessible: pdxscholar@pdx.edu. 


\title{
The Earliest American Map of the Northwest Coast
}

\author{
John Hoskins's A Chart of the Northwest \\ Coast of America Sketched on Board the Ship \\ Columbia Rediviva . . . 1791 \& 1792
}

JAMES V. WALKER AND WILLIAM L. LANG

JOHN BOX HOSKINS (1768-ca. 1824) created a remarkable map from his service as a clerk aboard the Columbia Rediviva on its second voyage to the Northwest Coast in 1790-1793, a map that is as revelatory as it is mysterious. The only other extant map from that voyage is a sketch chart of the mouth of the Columbia River created by the Rediviva's captain, Robert Gray. But Gray's sketch pales in comparison to Hoskins's map, which features a highly sophisticated rendering of Vancouver Island and the Columbia River. Most important, perhaps, the ninety-one place-names on the map include documentation of Native communities during a time when maritime fur traders and Native people had some of their earliest encounters in the region. A Chart of the Northwest Coast of America Sketched on Board the Ship Columbia Rediviva is the earliest extant rendering of the Northwest Coast by an American. With much more detail than any other map made at the time, it opens a window to what American traders knew, what they perceived about the region, and what they may have understood about the Native landscape.

The map's discovery is part of the story. Ralph Ehrenberg, then with the Cartographic Archives Division of the National Archives, first uncovered Hoskins's map in a file of maps that had been part of an 1852 petition to Congress from Gray's wife, Martha Gray. He knew it was important, but he did not know why Hoskins had created the map or what role it had played in the history of exploration. Without question, though, Ehrenberg knew that the map considerably expanded cartographic knowledge of the Northwest Coast, beyond what was available in circulating British maps from the early 1790 . 


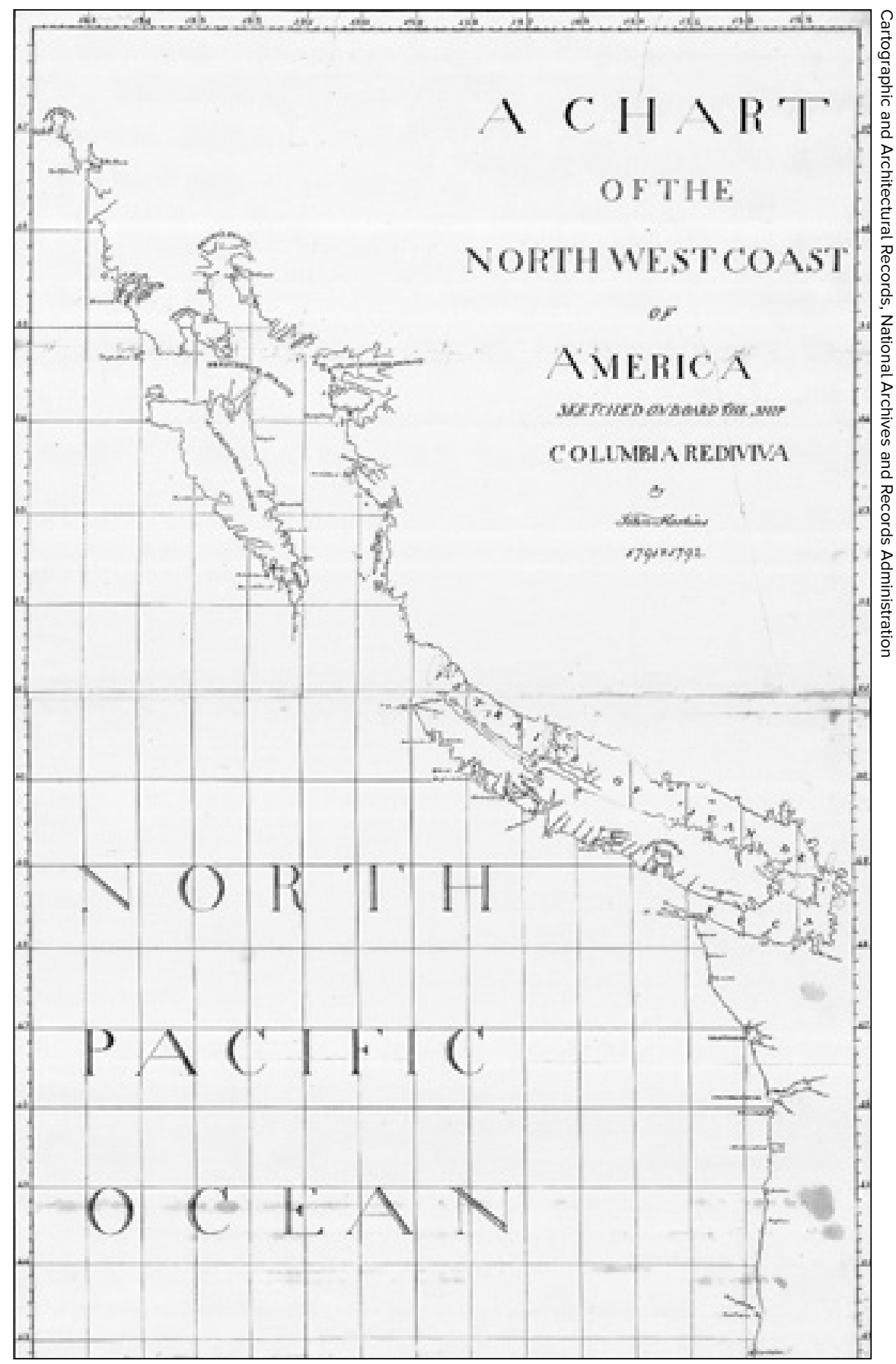

FIGURE 1: John Hoskins's manuscript "A Chart of the North West Coast of America ..." and three other smaller manuscript maps were removed from their location in the National Archives and Records Administration's Legislative Archives Division and transferred to the Cartographic Archives Division in the early 1970 . 
While the impact in America of Hoskins's map - how it was used and how its information was disseminated - is barely visible in the historic record, there is much to learn by investigating it. Given what we understand about the maritime fur trade, the dominance of British cartography in the early nineteenth century - especially the influence of George Vancouver's comprehensive maps published in 1798 - and the complex nexus of commerce, scientific inquiry, and imperial ambitions of the era, there is no doubt that this map is remarkable. Hoskins's striking rendition of Columbia's River (italicized names throughout this article are from the map) and his identification of Native names along the Northwest Coast provide a cartographic understanding of human geography that is much different from charts created by other fur traders. The historical details of Hoskins's life and his map provide a context for understanding the Northwest Coast during the late eighteenth century, but there are other questions to consider. What can we conclude about the long-term utility of maps made by mariners on the Columbia Rediviva? How did British and American mariners, government officials, and merchants use cartographic knowledge? And how did cartography and the knowledge gained from exploration serve the geopolitical and institutional interests of Britain and the United States?

\section{THE MAP}

John Hoskins began his career in a Boston merchant house in 1786 under the tutelage of Joseph Barrell, a principal owner of the Columbia Rediviva. ${ }^{1}$ Following the first voyage of the Columbia to the Northwest Coast in 1787-1790, which resulted in financial loss, Barrell employed Hoskins as a clerk for the second voyage with instructions to "give us a faithful account of all transactions." ${ }^{2}$ The twenty-two-year-old Hoskins heeded Barrell's orders, and the result is his Narrative, one of four first-hand accounts of the voyage. ${ }^{3}$ Both the original manuscript and a condensed version of it are incomplete, ending in March 1792, two months before the Columbia Rediviva first crossed into the river that Gray later named after the ship. Although Barrell's orders to Hoskins and Gray did not include mapmaking, Hoskins twice mentioned in his account that he had drawn a chart of a harbor; neither map has survived. $\mathrm{He}$ also expressed concern about his limited knowledge of geographical locations along the coast and their relationships for trade and profit. "We left Boston," he wrote in August 1791, "without being able to procure the voyages of any of those preceding navigators who have visited this coast for trade or discoveries since the late Captain Cook whose voyages give little or no information respecting the greater part of the trading coast." ${ }^{4}$ Because none 
of the principals on the Columbia's second voyage mention the map, and the only unequivocal reference to it occurred many years later in a 1852 Congressional document. We cannot determine with certainty when Hoskins drew his map. It is likely that he sketched out components during the voyage and completed it after returning to Boston in late 1793.

A Chart of the Northwest Coast of America Sketched on Board the Ship Columbia Rediviva by John Hoskins 1791 \& 1792 (Figure 1) measures 37 by 25 inches at the margins and is composed of two equally sized, joined sheets of laid paper. ${ }^{5}$ One-inch, separated chain lines (impressions in the paper left by the thick vertical wires of the paper mold), with the counter mark J WHATMAN, are laid across the chain line near the watermark of the Whatman Strasburg shield. ${ }^{6}$ The map is drawn on a Mercator's projection with an approximate calculated scale of 1:2,800,000. Precise latitude lines extend from $42^{\circ} 30^{\prime}$ to $58^{\circ}$ north and longitudes from $121^{\circ}$ to $136^{\circ}$ west of the Greenwich Meridian; both sets of coordinates are divided at ten-minute intervals. The lettering is carefully and artfully rendered, from large shaded characters to small coastal place-names. John Hoskins, the only scripted name on the chart, is similar to several other examples of Hoskins's signature on correspondence.

A few dotted lines representing the Columbia's tracks and "+" marks designating shoals appear inconsistently in various locations on the map. The coastal features extend from Norfolk Sound at $57^{\circ} 10^{\prime}$ in the northwest to Cape Orphod at $42^{\circ} 50^{\prime}$ to the southeast. Hoskins depicted a fascinating amalgam of directly observed features and conjectural geographical knowledge from sources that would have been available by early October 1792, when the Columbia left the Northwest on its return to Boston. He included archaic information that reflected long-standing beliefs in a transcontinental water passage across the North American continent, such as the Straits of Admiral De Fonte at $54^{\circ} 45^{\prime}$ and the River of the West at $43^{\circ} .^{7}$ Above President's Straits (modern-day Dixon Entrance), Hoskins drew on his own experience in August 1791, when the Columbia took refuge from fierce storms at Port Tempest in Brown's Sound (Clarence Strait, on the east side of Prince of Wales Island). For information farther north, Hoskins relied on Chief Mate Robert Haswell's observations in July 1792, when Haswell ventured the farthest north to Norfolk Sound in command of the newly built schooner Adventure. Hoskins was unfamiliar with the complexity of the Alexander Archipelago, but he captured much of the coastal topography of Washington's Islands (Haida Gwaii, or Queen Charlotte Islands) and the adjacent mainland from direct observation and likely from information obtained from Natives on the east side of those islands. Hoskins made it clear in his 


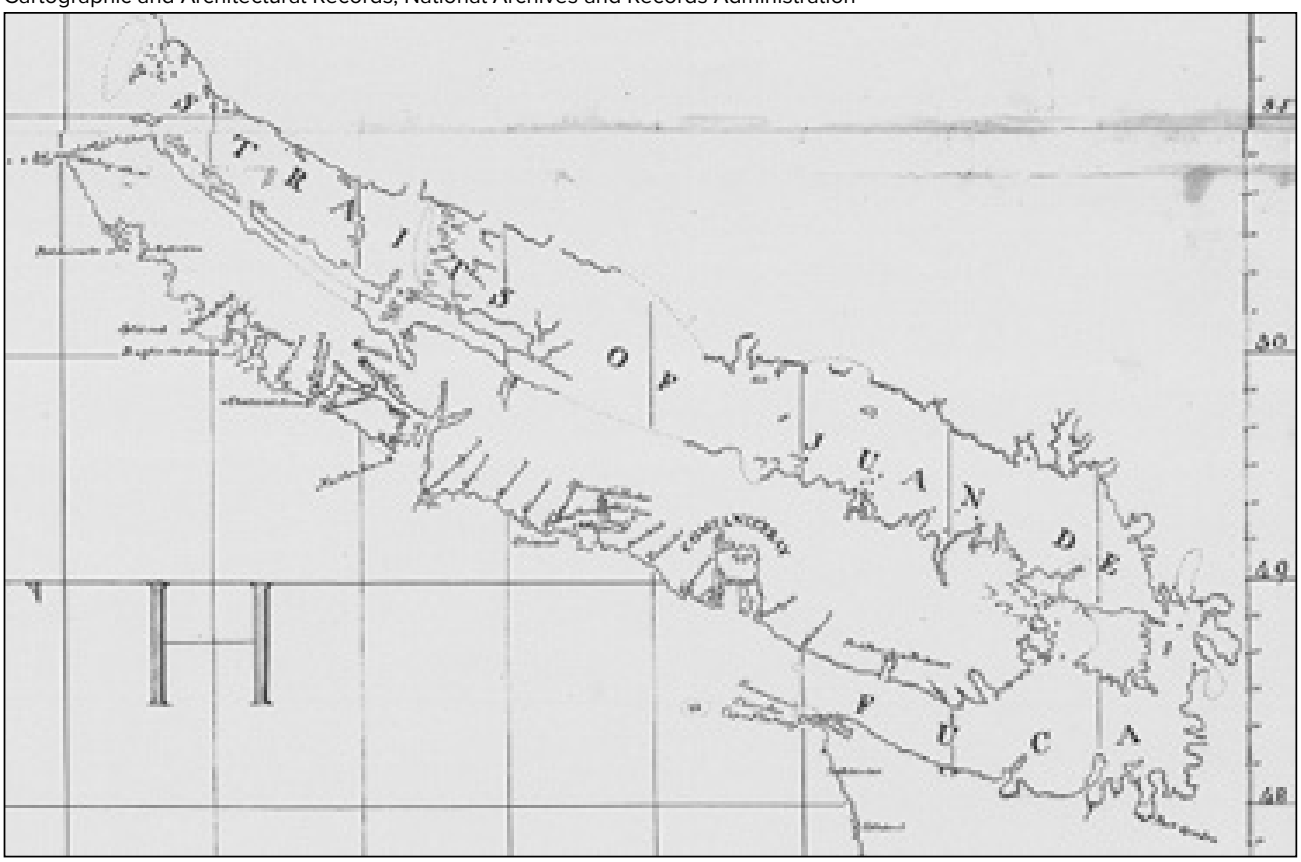

FIGURE 2: Detail of Hoskins's rendition of Vancouver Island (unnamed) suggesting incomplete knowledge of its insularity and topographical features of adjacent mainland.

Narrative that he frequently sought out Native people and queried them about their lives, locations of seasonal villages, dress, customs, and more.

During two seasons on the Northwest Coast, Gray pursued trade from north of Haida Gwaii ( $55^{\circ}$ north latitude) to the south, near the present-day Oregon and California state line $\left(42^{\circ}\right)$, with major stops in harbors from Vancouver Island to the Columbia River. On his map, Hoskins delineated the most remarkable geographical information between latitudes $46^{\circ}$ and $51^{\circ}$, along the western coast of modern-day Oregon, Washington, and Vancouver Island (Figure 2). He depicted the complexities of the sinuous passages and harbors of Nootka Sound, Clioquot (Clayoquot Sound), and Companie's Bay (Barkley Sound), where American and English ships had carried out much of their trade since 1785. Although the Columbia did not proceed very far into the Straits of Juan De Fuca, Hoskins rendered a tentative insular Vancouver Island bounded to the south and east by the Straits, suggesting that he had access to recent information from Spanish and British explorations. 
Seafaring officers of the three maritime nations, who competed for commercial and sovereign rights in the area, occasionally shared such cartographic information. In 1790, for example, Spanish captain Manuel Quimper sailed into the Straits of Juan de Fuca and named Port Quadra on July 13, although his maps showed no detail of the San Juan Islands or the Strait of Georgia. ${ }^{8}$ One year later, Francisco de Eliza reached Texada Island in the Strait of Georgia and prepared a map of his exploration, probably in early September 1791, titling it Carta que comprehende los interiers y veril de la Costa desde los $48^{\circ}$ de Latitud N. hasta los 50 . . Juan Carrasco, 1791 (Figure 3). ${ }^{9}$ Eliza's map leaves blank the region beyond approximately longitude $125^{\circ}$, but it includes the Spanish name Nuestra Senora del Rosario for part of the modern-day Strait of Georgia. Up to longitude $125^{\circ}$, Hoskins's map appears to be similar to Eliza's in several respects, including the appearance of the inlet leading to Port Quadra and the locations and naming of that port; the lack of any knowledge of Puget Sound, which Eliza had not explored; and the shape of a single island group in the region of San Juan Island at

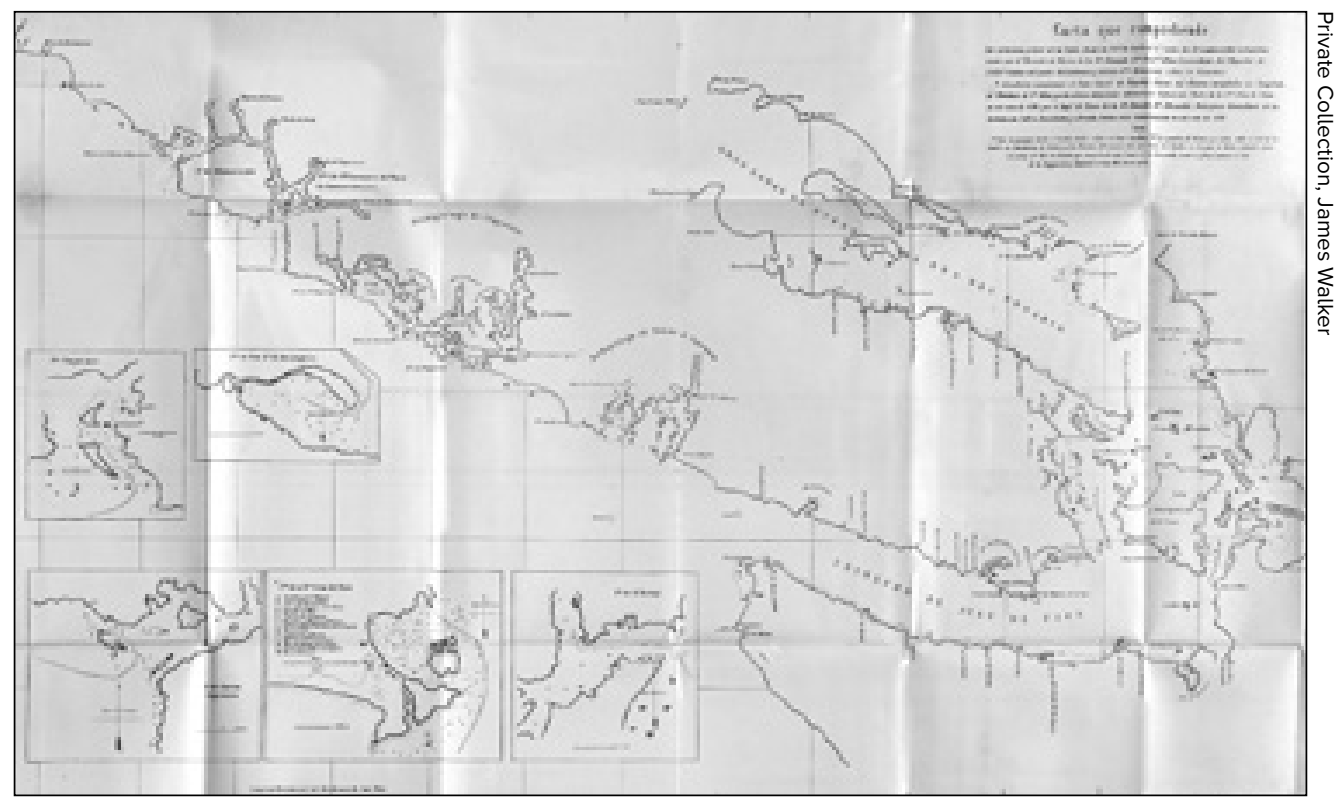

FIGURE 3: This highly detailed true copy of a manuscript map of Juan Carrasco during the voyage of Francisco de Eliza illustrates the state of Spanish knowledge of the topography of Vancouver Island, the Strait of Juan de Fuca, and adjacent waterways in 1791. (This copy was prepared by the United States as part of the Canal de Haro Arbitration, June 1972; original in Museo Naval, Madrid). 


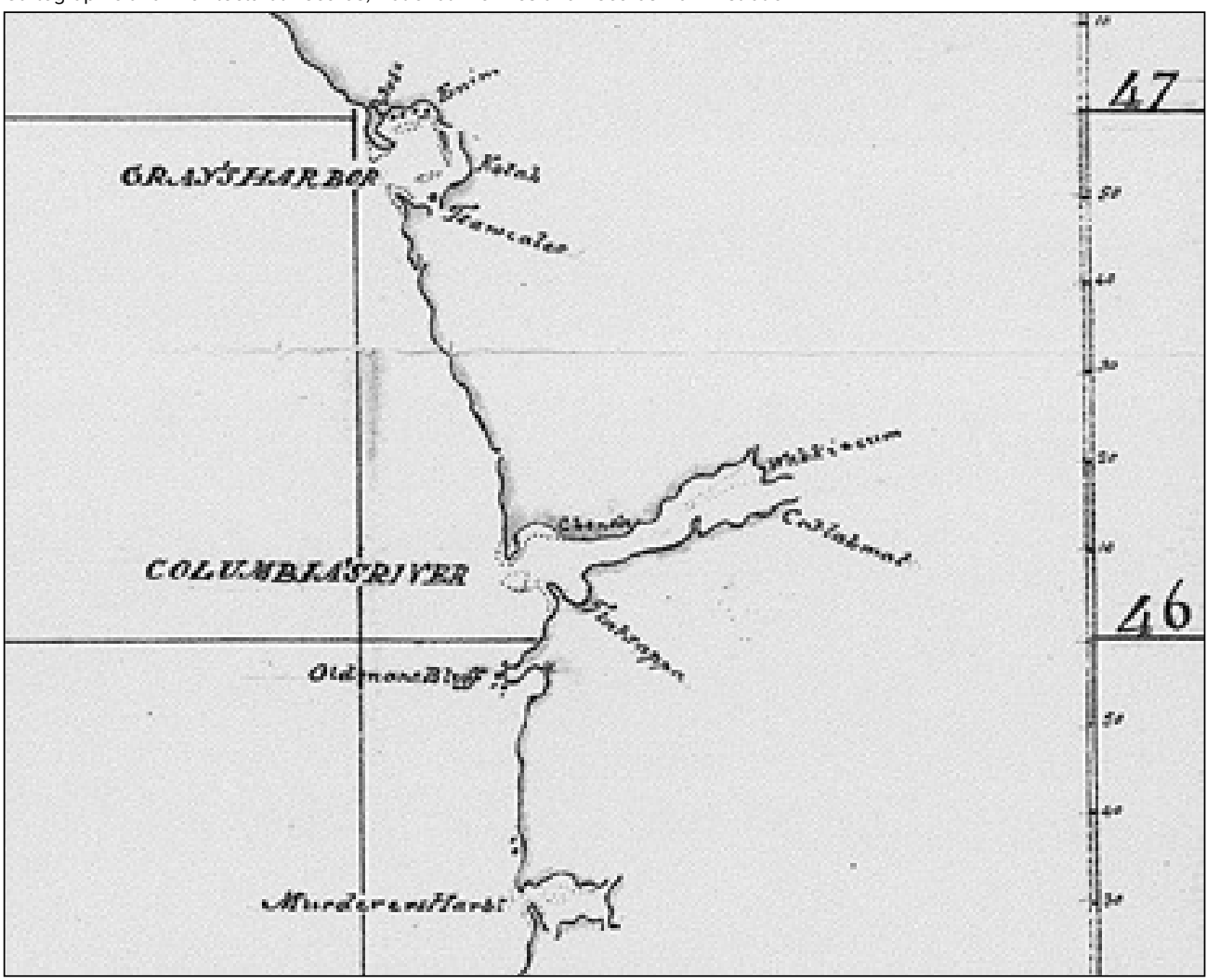

FIGURE 4: (Detail) Hoskins's illustration of Gray's Harbor and Columbia's River included the location of several named Native groups many of which remain in a similar locale in the lower Columbia River today. Modern names of the four groups in Columbia's River are Chinook, Wahkiakum, Cathlamet, and Clatsop.

the tip of Vancouver Island (Isla y Archipielago de S. Juan on Eliza's map and unnamed on Hoskins's map). All of this suggests that Hoskins examined and may have copied Eliza's map, probably between July 24 and August 23, 1792, while the Columbia was at Nootka under the hospitality of Juan Francisco de la Bodega y Quadra, commandant of the Spanish fort there.

There are also significant differences between Hoskins's and Eliza's maps. Hoskins did not include Texada Island as it appears on Eliza's chart, and he continued to depict an east coast of Vancouver Island separated from a British Columbia mainland, from longitude $125^{\circ}$ northwest and around the tip of the island at $129^{\circ}$, a suggestion of its insularity. British captain George 
Vancouver and Spanish captains Alcalá Galiano and Cayetano Valdés had circumnavigated the island in August 1792 before returning to Nootka, where Bodega entertained them on August 31. The Spanish captains left for Mexico that night. Three weeks later, on September 21, the Columbia re-entered Nootka Sound. The ship's officers missed Galiano and Valdés, but they met with Vancouver and exchanged information. "We mutually informed each other of our discoveries," Haswell wrote. "[Vancouver] went up the Straits of Juan de Fuca and surveyed it round and came out at Pintard's Straits [Haida Gwaii], and had discovered a passage to the north east, which he had not explored."10 The Americans and British departed Nootka on September 22, and it is difficult to know whether this brief stay was long enough for Hoskins to study Vancouver's charts. His map has no evidence of Puget Sound or any of the long inlets on the British Columbia mainland that Vancouver had surveyed earlier. But given Vancouver's information about the insularity of the island, Hoskins likely reasoned as John Boit had earlier: "Shou'd these straits [Pintard] join with Juan de Fuca, which perhaps it does, it must make the whole Coast [of Vancouver Island] between the Latitudes of $48^{\circ} 15^{\prime}$ and $51^{\circ} 30^{\prime}$ North and Longitudes $120^{\circ} 57^{\prime}$ and $129^{\circ} 30^{\prime}$ W. a vast Archipalago of Islsands." "11

It was south of Cape Flattery, along the coasts of modern-day Washington and Oregon, that Hoskins included his unique, direct observations of the voyage with depictions of Gray's Harbor and Columbia's River and Native communities (Figure 4). Dotted lines in the harbors indicate the ship's tracks, and it appears that he noted a sandbar at the entrance to Columbia's River. His view of Columbia's River is similar to Gray's (Figure 5), which may indicate that Hoskins had access to Gray's sketch map. The length of the river on Hoskins's map, for example, is approximately thirty-nine miles (using one degree of latitude on the map equivalent to sixty-nine miles). ${ }^{12}$ Gray calculated the length of the explored portion of Columbia's River at slightly less than forty miles (using his scale of three leagues to 1.75 inches).

The place-names on Hoskins's map are the product of his personal observations and information from multiple sources. Fifty of the ninety-one names are derived from Spanish, British, or American sources, and only four are of uncertain origin. ${ }^{13}$ Twenty-seven of the Euro-American-derived names were applied by Gray, Haswell, Joseph Ingraham, John Kendrick, or Hoskins on the first and second voyages of the Columbia, the Lady Washington, and the Adventure. The origins of the remaining, interpretable Euro-American names were from Cook's published map; from the Spanish commandant at Nootka, Bodega; from published accounts by George Dixon and John 


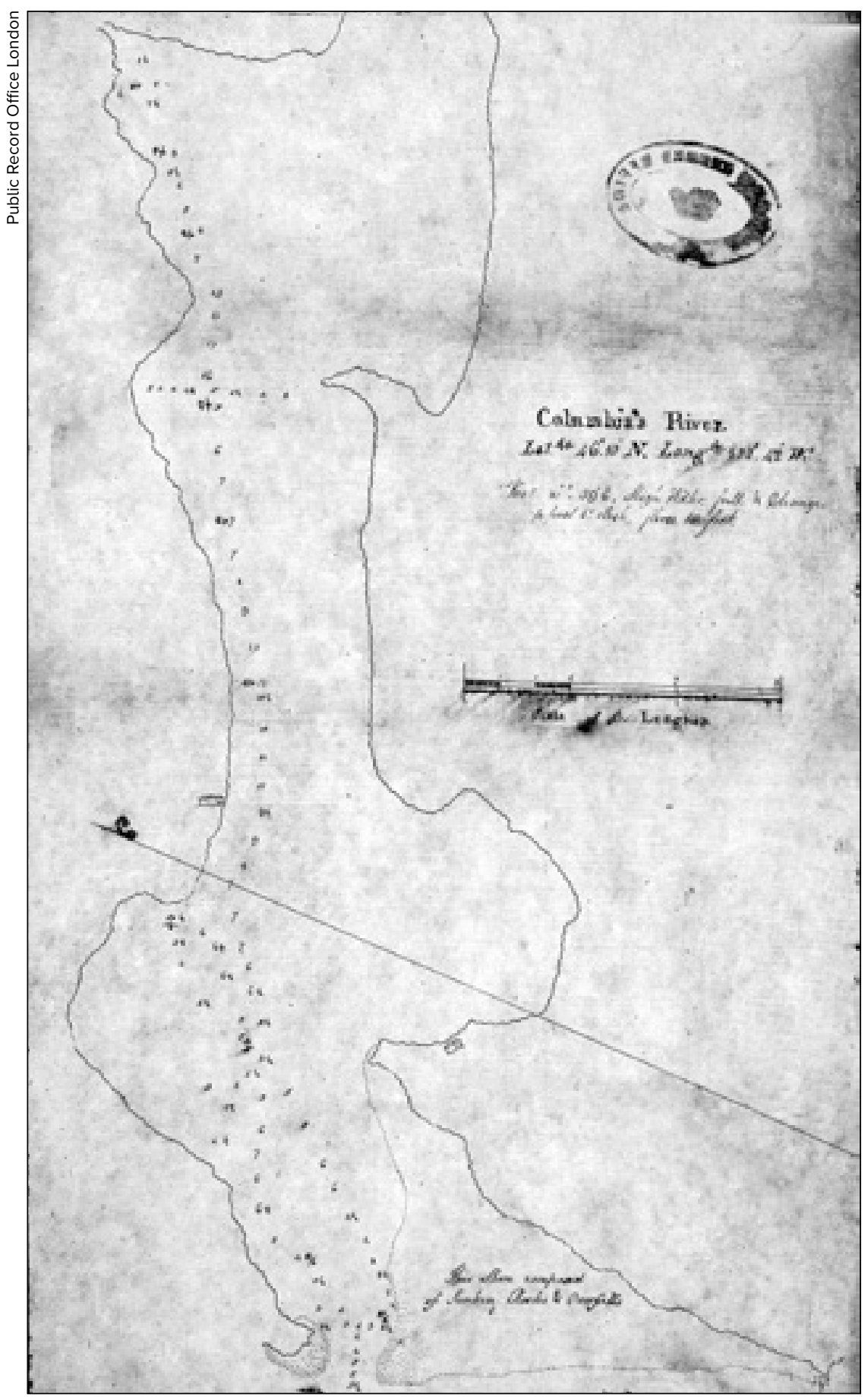

FIGURE 5: Manuscript map of Columbia's River (1792), a British copy of Robert Gray's map (no longer extant); north is to the left with the river's mouth at the bottom. 
Meares; and from long-standing cartographic misconceptions. ${ }^{14}$ Two names are noteworthy - Port Quadra, as already described, and Cape Orphod (at $42^{\circ} 50^{\prime}$ ) - because they reference sources of information that Hoskins could only have obtained from personal communication with Vancouver.

Hoskins knew all of these European and American sources before, during, or soon after the Columbia returned to Boston in late 1793. His additional notation of forty place-names from Native sources is quite remarkable. We found the origins of thirty-six of those names in the narratives of the voyage or in modern references..$^{15}$ Thirteen of them are not recorded in any of the accounts of the voyage published by F.W. Howay and were likely in the missing sections of Hoskins's and Haswell's narratives and the official log. Hoskins, for example, would not have observed coastal locations between the latitudes of $46^{\circ}$ and $48^{\circ}$ before April 1792, when his Narrative ends. According to Boit's log from April 1792, the Columbia proceeded as far south as $42^{\circ} 50^{\prime}$ on April 11 , before turning north. So it is likely that Hoskins took note of the ten Native names on his map between latitudes $46^{\circ}$ and $48^{\circ}$ and included them in the missing sections of his Narrative, between early April and October 3, when the ship finally left the Northwest Coast for Hawaii.

We can gain a better appreciation of Hoskins's notation of Native placenames by creating a comparative chart of the appellations. Tables 1 through 5 break down the Native names on his map into seven cultural groups encountered during the second voyage. In two locations, Hoskins included both English and Native names: Port Lincoln, or Mallahtea, and Port Poverty, or Pachenat. The tables include a few English names that appear on the map where the corresponding Native name appeared in one of the four accounts of the voyages. In most cases, though, the Native name Hoskins incorporated in his map has been identified by alternative pronunciations and spellings in contemporaneous and modern sources; many of them are listed in the column "Other Name." If it is known, we list the modern name equivalent of Hoskins's place-name. On occasion, Hoskins apparently used the name of a Native chief (for example, Caswhat) to identify a specific location. In other cases, he knew the locations of villages (for example, Newchatlet), but his incomplete understanding of the surrounding geography obscures the modern location. In several instances (for example, Oowhyet), the identification of the Native group Hoskins encountered has been lost. In some areas, such as Gray's Harbor, the near disappearance of speakers of the local language (in this case, Lower Chehalis) may account for the difficulty in identifying origin information on names such as Kotah. We include citations from the published narratives in Howay as well as a number of sources in the "Reference" column.

Hoskins heard names spoken in at least six language families, and he transcribed them phonetically. He knew that his interpretations were 


\section{TABLE 1: TRIBAL GROUP HAIDA}

\section{LANGUAGE FAMILY: Haida}

LOCATION: Southern Alaska and Eastern Queen Charlotte Islands (Haida Gwaii)

\begin{tabular}{|c|c|c|c|}
\hline $\begin{array}{l}\text { HOSKINS'S } \\
\text { NAME }\end{array}$ & $\begin{array}{l}\text { OTHER } \\
\text { NAME }\end{array}$ & MODERN NAME & REFERENCE \\
\hline Clegauhny & $\begin{array}{l}\text { Kaigahnee, } \\
\text { Kegonee, Kaigani }\end{array}$ & No longer present & Howay, 228, 323; Malloy, 186. \\
\hline Needen & Unknown & $\begin{array}{l}\text { Name of town chief; no } \\
\text { modern equivalent }\end{array}$ & Howay, 236. \\
\hline $\begin{array}{l}\text { Hancock's } \\
\text { River }\end{array}$ & $\begin{array}{l}\text { Masheet in } \\
\text { Hoskins's } \\
\text { Narrative }\end{array}$ & $\begin{array}{l}\text { Masset Harbor on } \\
\text { Graham island }\end{array}$ & $\begin{array}{c}\text { Howay, 229,233; Malloy, 191-92; } \\
\text { Wagner, 396, 461; Walbran, 323-24. }\end{array}$ \\
\hline Skitagits & Skiltikiss & $\begin{array}{l}\text { Name of town chief; now } \\
\text { Skidegate Inlet }\end{array}$ & $\begin{array}{l}\text { Howay, 236, 320; Wagner, 516; } \\
\text { Walbran, } 459 .\end{array}$ \\
\hline Tooscondolth & Tooschsondolth & $\begin{array}{l}\text { Name of town chief; now } \\
\text { Cumshewa Inlet }\end{array}$ & Howay, 214-15, 233; Walbran, 124. \\
\hline Caswhat & Unknown & $\begin{array}{l}\text { Name of town chief; no } \\
\text { modern equivalent }\end{array}$ & Howay, 236. \\
\hline Ugah & Uqua & $\begin{array}{l}\text { Name of town chief; now } \\
\text { Skincuttle Inlet }\end{array}$ & $\begin{array}{l}\text { Galois, 283; Howay, 201, 211, 236; } \\
\text { Malloy, } 202 .\end{array}$ \\
\hline Barrell's Sound & $\begin{array}{l}\text { Congethoitoy in } \\
\text { Hoskins's Narrative; } \\
\text { Magee's Sound } \\
\text { (Joseph Ingraham) }\end{array}$ & $\begin{array}{c}\text { Houston Stewart } \\
\text { Channel on Moresby } \\
\text { Island }\end{array}$ & $\begin{array}{l}\text { Howay, 98, 199, 202-03; Wagner, 431; } \\
\text { Walbran, 252-53. }\end{array}$ \\
\hline
\end{tabular}

\section{TABLE 2: TRIBAL GROUP NOOTKAN (NUU-CHAH-NULTH)}

LANGUAGE FAMILY: Wakashan (Nootkan Branch)

LOCATION: Western Vancouver Island

\begin{tabular}{|c|c|c|c|}
\hline $\begin{array}{c}\text { HOSKINS'S } \\
\text { NAME }\end{array}$ & $\begin{array}{c}\text { OTHER } \\
\text { NAME }\end{array}$ & MODERN NAME & REFERENCE \\
\hline $\begin{array}{c}\text { Port Lincoln or } \\
\text { Mallahtea }\end{array}$ & Unknown & Quatsino Sound & $\begin{array}{c}\text { Howay, 318; Wagner, 404; } \\
\text { Walbran, 409. }\end{array}$ \\
\hline Chicklaset & $\begin{array}{c}\text { Chickleset; Chick- } \\
\text { liset }\end{array}$ & Nasparti Inlet & $\begin{array}{c}\text { Howay, 85, 189, 193, 241, 302, 336; } \\
\text { Wagner, 436, 442. }\end{array}$ \\
\hline Kyuquot & $\begin{array}{c}\text { Cauquot, Cahoo- } \\
\text { quot, Cayuquet }\end{array}$ & Kyuquot Sound & Howay, 85, 189; Walbran, 294-95. \\
\hline
\end{tabular}


TABLE 2 (CONTD.): TRIBAL GROUP NOOTKAN (NUU-CHAH-NULTH)

\begin{tabular}{|c|c|c|c|}
\hline $\begin{array}{l}\text { HOSKINS'S } \\
\text { NAME }\end{array}$ & $\begin{array}{l}\text { OTHER } \\
\text { NAME }\end{array}$ & MODERN NAME & REFERENCE \\
\hline $\begin{array}{l}\text { Kendrick's } \\
\text { Harbour }\end{array}$ & $\begin{array}{c}\text { Mahwina, } \\
\text { Mahwiank, } \\
\text { Mawinna, } \\
\text { Mowenna, } \\
\text { Kendrick's Cove }\end{array}$ & Marvinas Bay & $\begin{array}{c}\text { Howay, } 82,100,163,241 \text {; Walbran, } \\
321 .\end{array}$ \\
\hline Quahik & Unknown & Unknown & Unknown \\
\hline $\begin{array}{l}\text { Ahataset } \\
\text { Sound }\end{array}$ & Ahatasut & $\begin{array}{l}\text { Unknown location in } \\
\text { Esperanza Inlet }\end{array}$ & $\begin{array}{l}\text { Howay, } 107,241-42,317 ; \\
\text { U.S. Congress, } 23 .\end{array}$ \\
\hline Newchatlet & $\begin{array}{l}\text { New Chatleck; } \\
\text { Hoot-see-ess }\end{array}$ & $\begin{array}{l}\text { Nuchatl in Esperanza } \\
\qquad \text { Inlet }\end{array}$ & U.S. Congress, 23. \\
\hline Tashee & Tasis & Tahsis in Esperanza Inlet & $\begin{array}{l}\text { Hodge, 695; Howay, 241; } \\
\text { U.S. Congress, } 24 .\end{array}$ \\
\hline Nootka Sound & $\begin{array}{l}\text { King George's } \\
\text { Sound }\end{array}$ & Nootka Sound & $\begin{array}{l}\text { Howay, throughout; Wagner, 400; } \\
\text { Walbran, 359-62. }\end{array}$ \\
\hline Esquoat & Esquoot & Hesquiat Harbor & Howay, 188, 259; Walbran, 240,242. \\
\hline Manouset & $\begin{array}{l}\text { Manoish?; } \\
\text { Manoisat; } \\
\text { Manhousat }\end{array}$ & $\begin{array}{l}\text { Unknown location; } \\
\text { previously in Sidney Inlet } \\
\text { and merged with other } \\
\text { groups }\end{array}$ & $\begin{array}{l}\text { Drucker, 238; Howay, 107; Suttles, } \\
\text { 392-93. }\end{array}$ \\
\hline Elouset & Otsosat? & Unknown location & $\begin{array}{l}\text { Drucker, 238; Howay, 107; Suttles, } \\
\text { 392-93. }\end{array}$ \\
\hline Ahouset & $\begin{array}{c}\text { A'howset, } \\
\text { Ahousaht; } \\
\text { Ahhousett, Ahasset }\end{array}$ & $\begin{array}{l}\text { Ahousat on Flores or } \\
\text { Blunden Island }\end{array}$ & $\begin{array}{c}\text { Drucker, 238-39; Galois, 276; Howay, } \\
\text { 67, 369; Suttles, 392-93; U.S. Con- } \\
\text { gress, 21; Walbran, } 14 .\end{array}$ \\
\hline Clioquot & $\begin{array}{l}\text { Hancock's Harbour, } \\
\text { Cox's Harbour, } \\
\text { Clayquot }\end{array}$ & Clayoquot Sound & $\begin{array}{c}\text { Drucker, 240-43; Howay, 18, 45, 68, } \\
\text { 182, 189, 278-80; Malloy, 178-79; } \\
\text { Suttles, 392-93; Walbran, 92-4. }\end{array}$ \\
\hline Adv. ${ }^{t}$ Cove & Clicksclecutsee & ?on Meare's Island? & Howay, 277 and $n 381$. \\
\hline Ohcot(?)hlet & ?Uchucklesaht? & Unknown & Unknown \\
\hline Youthlulet & $\begin{array}{l}\text { Youchehtaht, You- } \\
\text { clul-aht, Ucle-Teh }\end{array}$ & $\begin{array}{l}\text { Ucluelet tribe on north } \\
\text { entrance of Barkely } \\
\text { Sound }\end{array}$ & Hodge, 862; Suttles, 392-93. \\
\hline Tuqccahet & Toquaht & $\begin{array}{c}\text { Former village on } \\
\text { Toquaht Bay and western } \\
\text { Barkely Sound }\end{array}$ & Suttles, 392-93. \\
\hline
\end{tabular}


TABLE 2 (CONTD.): TRIBAL GROUP NOOTKAN (NUU-CHAH-NULTH)

\begin{tabular}{|c|c|c|c|}
\hline $\begin{array}{l}\text { HOSKINS'S } \\
\text { NAME }\end{array}$ & $\begin{array}{l}\text { OTHER } \\
\text { NAME }\end{array}$ & MODERN NAME & REFERENCE \\
\hline Hichacht & $\begin{array}{l}\text { Hichaht; Hichahats, } \\
\text { Highshakt }\end{array}$ & $\begin{array}{l}\text { Unknown location in } \\
\text { Barkely Sound, no longer } \\
\text { present }\end{array}$ & Howay, 268-69, 313, 317. \\
\hline Oowhyet & $\begin{array}{l}\text { Ohiaht, Ohyaht, } \\
\text { Ohyato, Oiaht }\end{array}$ & $\begin{array}{l}\text { Unknown location in east } \\
\text { Barkley Sound, no longer } \\
\text { present }\end{array}$ & Suttles, 110, 392-93. \\
\hline Nittenat & Nitinat & $\begin{array}{l}\text { Nitinat village in east } \\
\text { Barkley Sound }\end{array}$ & $\begin{array}{c}\text { Galois, 281-82; Howay, 71, 81, } \\
\text { 195-96, 198, 371; Malloy, 176; Suttles, } \\
\text { 392-93. }\end{array}$ \\
\hline $\begin{array}{l}\text { Port Poverty or } \\
\text { Pachenat }\end{array}$ & $\begin{array}{l}\text { Poverty Cove or } \\
\text { Bay, San Jan de } \\
\text { Pachina (Spanish), } \\
\text { Port Hawkesbury }\end{array}$ & Port San Juan & $\begin{array}{c}\text { Howay, 71, 73, 80, 197, 354, 417; } \\
\text { Wagner, } 410 .\end{array}$ \\
\hline
\end{tabular}

\section{TABLE 3: TRIBAL GROUP MAKAH}

LANGUAGE FAMILY: Wakashan (Nootkan Branch)

LOCATION: Olympic Peninsula

\begin{tabular}{|c|c|c|c|}
\hline $\begin{array}{l}\text { HOSKINS'S } \\
\text { NAME }\end{array}$ & $\begin{array}{l}\text { OTHER } \\
\text { NAME }\end{array}$ & MODERN NAME & REFERENCE \\
\hline Keeneecomit & Kenekomitt? & Uncertain location & Howay, 392-393 and f/n.* \\
\hline Chandee & Chandie, Chahnee & Unknown location & Howay, 74-75,81,243,300) \\
\hline Neah & Nee'ah, Ne-ar & Neah Bay & $\begin{array}{l}\text { Hitchman, 205; Howay, 74, 355, } \\
\text { 415-416. }\end{array}$ \\
\hline Claheset & $\begin{array}{l}\text { Claaset, Clisseet, } \\
\text { Clahaset }\end{array}$ & Classet of Cape Flattery & $\begin{array}{l}\text { Galois, 277; Hitchman, 50; Howay, } \\
\text { 72, 266; Malloy, } 178 .\end{array}$ \\
\hline Ashenhat & Unknown & Unknown location & Howay, 245 (Ahshewat); Malloy, 178. \\
\hline
\end{tabular}


TABLE 4: TRIBAL GROUPS QUILEUTE, QUINAULT, AND LOWER CHEHALIS

LANGUAGE FAMILY: Chimakuan and Salishan (Tsamosan Branch)

LOCATION: North-Central Coast Washington State and Gray’s Harbor

\begin{tabular}{|c|c|c|c|}
\hline $\begin{array}{l}\text { HOSKINS'S } \\
\text { NAME }\end{array}$ & $\begin{array}{l}\text { OTHER } \\
\text { NAME }\end{array}$ & MODERN NAME & REFERENCE \\
\hline Collehout & $\begin{array}{l}\text { Quillehute, Qual- } \\
\text { layute, Quillayute, } \\
\text { Goliew }\end{array}$ & Quileute & $\begin{array}{l}\text { Hitchman, 245; Howay, 394; Suttles, } \\
\text { 35, 40, 431-37; Olson, 38-39. }\end{array}$ \\
\hline Queenlith & Quunelth, Quinelth & Quinault & $\begin{array}{c}\text { Hitchman, 245; Howay, 41; Suttles, } \\
\text { 35, 38-39, 503-17; Olson, 503-504, } \\
\text { 513-15; Wagner, } 488 .\end{array}$ \\
\hline Potosa ${ }^{\S}$ & Potoashs & $\begin{array}{c}\text { Unknown near Gray's } \\
\text { Harbor }\end{array}$ & Bancroft, зоз. \\
\hline Enina? ${ }^{\S}$ & Unknown & $\begin{array}{c}\text { Unknown in Gray’s } \\
\text { Harbor }\end{array}$ & Unknown \\
\hline Kotah $^{\S}$ & Unknown & $\begin{array}{l}\text { Unknown in Gray's } \\
\text { Harbor }\end{array}$ & Hodge, Part 2, 1078. \\
\hline Tsa(?)cales ${ }^{\S}$ & $\begin{array}{l}\text { Chehalis, Tsihalish, } \\
\text { Chi-ke-lis }\end{array}$ & $\begin{array}{l}\text { Unknown- possibly origi- } \\
\text { nal "Chehalis" village in } \\
\text { southern Gray's Harbor }\end{array}$ & Hitchman, 44; Olson, 516. \\
\hline
\end{tabular}

* Howay believes that the village of Kenekomitt mentioned in Boit's account corresponds to a now-unoccupied site near Teakwhit Head near the mouth of the Quillayute River. If this is the case, Hoskins misplaced the location of the village farther north to the area of Cape Flattery.

+ Howay believes Hoskins's Ahshewat is equivalent to the village Classet near Cape Flattery. Hoskins's map locates Ashenhat farther south on the coast. It is unclear if these two similar names are one and the same village and, therefore, an error attributed to Howay or Hoskins.

‡ Howay’s reference from Haswell's first log notes the location of the Quunelth village farther north than Queenlith on the map. In the eighteenth century, the Quinault Indians ranged extensively along the coast of present-day Washington state.

§ The four Native names within and near to Gray's Harbor are difficult to interpret. Potosa may be equivalent to the Potoashs, a coastal Washington tribe mentioned in Bancroft (citing an 1822 report by Jedidiah Morse). Tsa(?)cales on the southern side of Gray's Harbor is inferred as Chehalis by location only. The authors were unable to identify the origin of the names Kotah and Enina(?). 


\section{TABLE 5: TRIBAL GROUP CHINOOKANS}

\section{LANGUAGE FAMILY: Chinookan}

LOCATION: Columbia River

\begin{tabular}{|c|c|c|c|}
\hline $\begin{array}{c}\text { HOSKINS'S } \\
\text { NAME }\end{array}$ & $\begin{array}{c}\text { OTHER } \\
\text { NAME }\end{array}$ & MODERN NAME & REFERENCE \\
\hline Chenoke & $\begin{array}{c}\text { Chinook, Chinoak, } \\
\text { Chinouk, Chenoke }\end{array}$ & $\begin{array}{c}\text { Chinook village on north } \\
\text { bank of Columbia River }\end{array}$ & $\begin{array}{c}\text { Bancroft, 223; Hitchman, 47; Howay, } \\
\text { 398, 437; Olson, 533-35. }\end{array}$ \\
\hline Wahkiecum & $\begin{array}{c}\text { Wahkiakum, } \\
\text { Wakiacum }\end{array}$ & $\begin{array}{c}\text { Wahkiakum village on } \\
\text { north bank of Columbia } \\
\text { River }\end{array}$ & $\begin{array}{r}\text { Bancroft, 223; Hitchman, 321; } \\
\text { Olson, 534. }\end{array}$ \\
\hline Catlahmat & Cathlamet & $\begin{array}{r}\text { Cathlamet village on } \\
\text { south bank of Columbia } \\
\text { River }\end{array}$ & $\begin{array}{c}\text { Bancroft, 223; Hitchman, 40; McAr- } \\
\text { thur and McArthur, 180; Olson, 534. }\end{array}$ \\
\hline Tlatsappa & Clatsops, Tlahsops & $\begin{array}{c}\text { Clatsop village on south } \\
\text { bank of Columbia River }\end{array}$ & $\begin{array}{r}\text { Bancroft, 223; McArthur and McAr- } \\
\text { thur, 207. }\end{array}$ \\
\hline
\end{tabular}

\section{TABLE SOURCES}

Bancroft, Hubert Howe. The Native Races of the Pacific States of North America, Vol. 1, Wild Tribes. New York: D. Appleton and Company, 1875.

Drucker, Philip. The Northern And Central Nootkan Tribes. Smithsonian Institution Bureau of American Ethnology Bulletin 144. Washington: Government Printing Office, 1951.

Galois, Robert, ed. A Voyage to the North West Side of America: The Journals of James Colnett, 1786-89. Vancouver: UBC Press, 2004.

Hitchman, Robert. Place Names of Washington. Seattle: Washington State Historical Society, 1985. Hodge, Frederick Webb, ed. Handbook of North American Indians North of Mexico. Washington: Government Printing Office, Part 1, 1907, and Part 2, 1910.

Howay, Frederic W., ed. Voyages of the Columbia to the Northwest Coast 1787-1790 \& 17901793. Portland: Oregon Historical Society Press in cooperation with The Massachusetts Historical Society, 1990.

Malloy, Mary. "Boston Men" on the Northwest Coast: The American Maritime Fur Trade 17881844. Kingston and Fairbanks: the Limestone Press and University of Alaska Press, 1998.

McArthur, Lewis, A. and Lewis L. McArthur. Oregon Geographic Names, seventh edition. Portland: Oregon Historical Society Press, 2003.

Olson, Ronald L. The Quinault Indians. Seattle: The University of Washington: 1936.

Suttles, Wayne, ed. Handbook of North American Indians, Volume 7: Northwest Coast. Washington: Smithsonian Institution, 1990.

U.S. Congress. Senate Report 335 to accompany Senate Bill No. 526, 32d. Cong, 1st Sess., August 11, 1852, 1-22.

Wagner, Henry R. The Cartography of the Northwest Coast of America to the Year 1800. Amsterdam: N. Israel, 1968.

Walbran, Cap. John T. British Columbia Coast Names 1592-1906. Vancouver and Toronto: Douglas \& McIntyre, 1977. 
imprecise, as he noted in text accompanying a compilation of Native words in his Narrative: "I here subjoin a list of words I was able to procure which are spelt as near to their pronunciation as my ear would direct which I am conscious is far from being right." ${ }^{16}$ Only a few of the place-names applied by Hoskins, Gray, and other fur traders survive, including Kyuquot, Ahousat, Neah, Gray's Harbor, and Columbia River.

Hoskins's map is also an economic document. It is one of the earliest visual records of cartographic representations of Native communities on the Northwest Coast between northern latitudes $46^{\circ}$ and $55^{\circ}$, a cartographic guide that his employer surely would have understood as valuable. The maritime pelagic fur trade on the Northwest Coast took place around Native villages, where exchanges garnered furs that brought high prices in China. In part, Hoskins's chart is an exercise in mapping the powerful relationship between commerce and cartography on the Northwest Coast, one of many such charts in the late eighteenth century. In 1774, 1775, and 1779, Spanish naval expeditions had explored and mapped extensive sections of the Pacific Coast from San Blas, Mexico ( $22^{\circ} 54^{\prime}$ north), to the vicinity of Prince William Sound $\left(60^{\circ} 17^{\prime}\right)$; and even though Spanish policy had precluded the publication and dissemination of travel narratives and charts, some accounts of these voyages had reached England. ${ }^{17}$

It was the publication in 1784 of Voyage to the Pacific Ocean, the journals and charts from the expedition of Captain James Cook and Captain James King (1776-1780), that unleashed a fur-trade rush to the Northwest Coast. The publication reported an astonishing potential trade in Asian markets for fur-bearing pelagic animals acquired in the Northwest. Cook's charts guided fur traders to locations of Native communities at Nootka Sound (also known as King George's Sound) on Vancouver Island and elsewhere in the region. But these same charts depicted extensive areas, between latitudes $46^{\circ}-50^{\circ}$ and $51^{\circ}-55^{\circ}$, where adverse sailing conditions prevented Cook from directly observing the coast and locales that fur-trading captains understood had potentially great economic value. In September 1788, for example, British trader and ship owner John Meares included in his instructions to Captain William Douglas: "As you steer along the N.W. side of the great Island [Haida Gwaii], you will explore it minutely to the height of $54^{\circ}$ where resides a chief whose district is large. ... Between this chief's residence and Cape S. James lies a part of the Continent unexplored and we may not flatter ourselves vainly that in such an extent of Land there reside many Chiefs and numerous Inhabitants. Strange as it may appear, I believe it nevertheless true that Captain Cook never saw any part of the Continent of America until he reached $60^{\circ}$ of latitude."18

From 1785 until the publication of George Vancouver's detailed survey charts in 1798, the reports and charts of maritime fur-trade explorers generated all of the new geographical knowledge of the Northwest Coast. From 
1785 to 1795 , an estimated thirty-five British and fifteen American ships traded on the coast from approximately $42^{\circ}$ to $60^{\circ}$ north latitude. This ratio reversed during the next two decades, with American ships outnumbering the British by nearly ten to one. ${ }^{19}$ The predictable outcome of this unregulated harvest of a marginally renewable resource was the disappearance of the sea otter by the 1830 s. Many of the ships traded during more than one season, which usually lasted from June to September, but they rarely spent more than three years on the coast. Cartography was linked to profit, and knowledge of the locations of potential new markets was proprietary. But the value of Hoskins's chart must have diminished for his employers, because they decided not to sponsor further ventures to the Northwest Coast after the Columbia returned to Boston in 1793.

Many ships' captains, officers, and crew compiled logs or journals, and some drew charts, ranging from extensive coastal regions to large-scale harbor views, creating documents that record early encounters with indigenous people and first-hand observations of coastal geographies. Survival of those records depended on many factors. The maritime fur trade was an intensively competitive industry, with profits depending to some degree on controlling or falsifying information about Native trading communities. ${ }^{20}$ Prior to his trading voyage of 1785-1786, for example, British captain James Strange stipulated that all participants "shall deliver to James Strange Esq., on his order, their Journals and all the Papers respecting the Voyage when so required by him." ${ }^{21}$ This practice was rarely effective. Journals were often written after a voyage was completed, and once in private hands, were often put aside and left incomplete; maps were separated from the text, and sections lost or purposefully destroyed. Of the four extant journals of the second voyage of the Columbia, the accounts of Haswell and Hoskins are incomplete either because they were lost or not finished, and a large part of Gray's journal was destroyed when used as waste paper. ${ }^{22}$

The surviving correspondence of the officers and principal owners of the Columbia includes no specific references to Hoskins's chart of the Northwest Coast. Hoskins mentioned two of his charts in his Narrative, one of New Island Harbor in the Falkland Islands and a sketch of Harbour Island near Clayquot Sound, but neither survive. ${ }^{23}$ It seems likely that he completed his chart of the Northwest Coast at the same time he drew sketches of the two harbors, but there is no information about how or when that chart was separated from the others. Other crew members certainly made maps, and several survive; but no coastal maps by Gray have been found, although an English copy of Gray's sketch map of Columbia's River was discovered in the Public Records 
Office in London in 1961. Joseph Ingraham, second mate on the Columbia's first voyage, compiled a journal and drew several maps of the Northwest Coast after his 1790-1793 voyage to the region in the ship Hope. ${ }^{24}$ Robert Haswell, first mate on Columbia's second voyage, drew several charts of ports, which he included in his journal. ${ }^{25}$ Correspondence suggests that several additional maps were lost over time. On August 25, 1800, Haswell asked Gray to send him a copy of "My Chart of the NW. Coast." ${ }^{26}$ On August 5, 1801, in preparation for his imminent departure on a fur-trading voyage to the Northwest Coast, Haswell wrote Joseph Barrell: "As I have no copy of my chart of the N.W. coast and it will be very essential to refresh my memory by frequent perusal of it, I would take it as a favor if you would lend that to me which you have in your possession ... when I will return it with another more complete and worthy of acceptance." ${ }^{27}$ Barrell's response is not known, and Haswell was lost at sea on that voyage. Finally, in an April 1820 letter to a surviving owner of the Columbia, Charles Bulfinch, Boit wrote that he had seen a letter from Bulfinch to owner Sam Brown. Boit concluded: "it appears that you have had an opportunity of examining the Journals of the late Capt Gray and Mr. Haswell, \& have likewise seen the charts, which where [sic] drafted upon the spot." 28

In an ironic twist, the potential economic value of Hoskins's map resurfaced much later. By the mid 1820s, the United States and Great Britain were engaged in diplomatic negotiations over territorial claims in the Pacific Northwest, with significant geopolitical interests and economic resources at stake. ${ }^{29}$ To bolster their claims, American negotiators depended heavily on the actions taken by officers during the two voyages of the Columbia. Several relatives of the earliest American ship owners and traders to the Northwest Coast subsequently applied to the United States government for compensation related to the actions of their forbearers. In July to August 1791, American fur trader John Kendrick negotiated what he interpreted were outright purchases of extensive tracts of land from Mowachaht chiefs in and around Nootka Sound. In April 1838 and again in June 1840, relatives of Kendrick and Charles Bulfinch, along with heirs of other owners of the Columbia, petitioned for "confirmation of their Indian titles to certain lands on the northwest coast of America" based on Kendrick's alleged legal purchases in $1791 .^{30}$ The petitioners included Martha Gray, Robert Gray's wife, who in January 1846 submitted the first of several memorials to Congress seeking remuneration "for the aged widow and unprotected daughters of the man who first unfurled the flag of our country upon the great river of the West." ${ }^{31}$

In February 1850, Missouri Senator Thomas Hart Benton presented a memorial on behalf of the heirs of Martha Gray and the purported landowners, 
seeking titles to tracts in Oregon Territory. Citing the body of evidence that his petitioners had submitted in support of their claim, Benton wrote: "there are some matters of historical interest among the papers presented, and many original papers which have never been published." ${ }^{32}$ The Senate Committee on Public Lands received the petition and accompanying evidence. The committee chair, Michigan Senator Alpheus Felch, delivered an extensive report on August 11, 1852, with references to the material evidence, that included "an original map of the northwest coast by John Hoskins, super cargo of the ship Columbia, bearing date of 1791 and 1792, upon which the coast and river is laid down as well as the island of Vancouver and the straits, with a striking degree of accuracy for that early period, and proving incontestably that this river, which is found on no previous map or chart, was explored and mapped." ${ }^{33}$ In April 1854, the committee ruled against the petitioners and referred them to the Committee on Claims to pursue monetary compensation.

Hoskins's map does not appear in further deliberations of any Congressional committees, but it likely was bound up with other evidence and placed in storage in the Capitol or a Senate office building. ${ }^{34}$ At some point, those papers were transferred to the National Archives building, constructed in 1934, and placed in the Center for Legislative Archives, where they can be found today. ${ }^{35}$ In October 1970, an archivist separated Hoskins's map and three others from the textual documents and transferred them to the Center for Cartographic and Architectural Archive branch. Soon after, Ehrenberg found the map and initiated a personal file for it. Some years later, Ehrenberg showed the file to Jim Walker, one of the authors of this article. And so it is that Hoskins's exceptional map exists as an orphaned record whose purpose of production and subsequent provenance are poorly documented and whose eventual use bore little relationship to the context in which it was created.

\section{THE HOSKINS MAP AND FUR-TRADE CARTOGRAPHY}

From 1785 to 1798 , mariners on privately sponsored British and American furtrading voyages spread knowledge through the exchange of maps, printed narratives, publications of commercial cartographers, and pamphlets and maps created by geographic experts. These exchanges of information, maps, and navigation tips generally occurred among fellow countrymen, but the exchanges among American, British, and Spanish mariners were some of the most remarkable examples of this practice. At Nootka Sound sometime between July and September 1792, Gray, Hoskins, Vancouver, and Bodega shared information on the location of the Columbia River and the geography of Vancouver Island. ${ }^{36}$ In June or September that year, Gray exchanged information about the Columbia River with Joseph Ingraham (second mate on the 
first voyage of the Columbia), then captain of the Hope, who was directly competing with Gray for furs. In his manuscript account of that voyage, Ingraham credits Gray with giving him geographical information of the coast south of Cape Flattery. Ingraham's "Chart of the West Coast America South of the $\mathrm{S}^{\text {t. }}$ De Fuca" clearly illustrates Columbia's River, a place he never personally encountered (Figure 6). ${ }^{37}$ Boit, the sixteen-year-old fifth mate on the Columbia, also retained information about named areas on the Columbia River. Later, as captain of the Boston-based Union during a trading voyage to the Northwest Coast, Boit wrote in his log on July

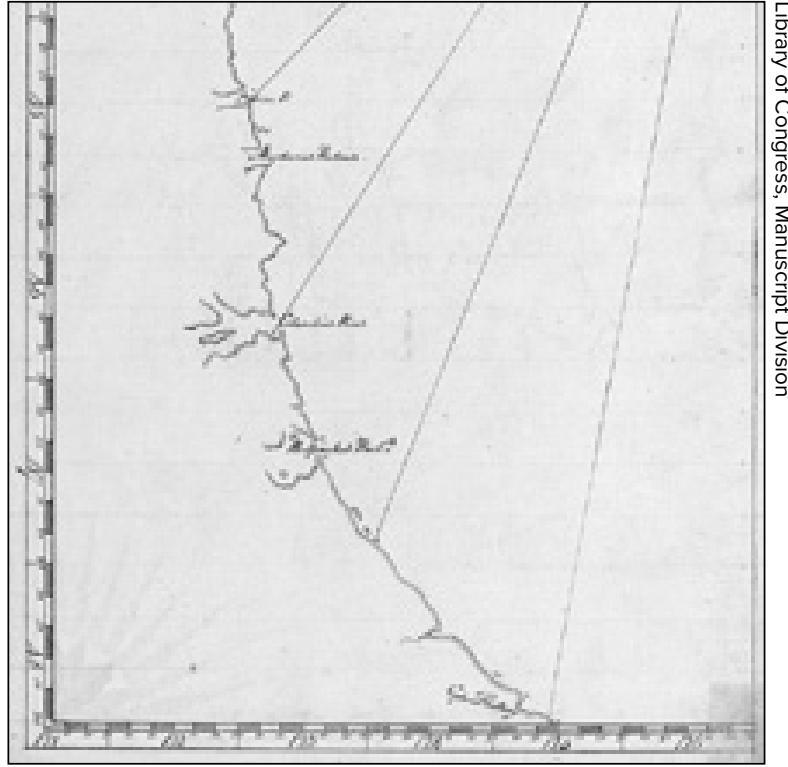

FIGURE 6: Part of Joseph Ingraham's manuscript chart (ca. 1792) of the Northwest coast of America; north towards the bottom. Ingraham drew this section largely from information supplied by Gray and Hoskins. Listed from north to south: Cape Flattery, Bullfinches Harb. (Gray's Harbor), Columbia's River, Murderous Harbour (Tillamook Bay), Pigeon R. (Salmon River).

11, 1795: "set sail and bore away for Columbia's river."

On July 12, he recorded that he "saw Cape Hancock" (Cape Disappointment) and on July 15, "Point Adams." ${ }^{8}$ News of Gray's discovery of potential trading opportunities on the Columbia River also may have been passed among other Boston ships' captains operating on the Northwest Coast. In September 1793, for example, Boston first mate Bernard Magee, on the Jefferson in Nootka Sound, learned that his tender, the Resolution, had traded successfully on "gray's river," a reference to the Columbia River. ${ }^{39}$ Reports of Gray's observations and his typonomy, however, may not have passed so readily to the captains of British fur-trading ships. In September 1794, for example, Sidenham Teast, owner of the Ruby, instructed Captain Charles Bishop to "trade the [Northwest] up to Port Sidenham [Gray's Murderers Harbor at 43 ${ }^{\circ} 50^{\prime}$ ]" and "from Port Sidenham you will proceed examining the coast to Deception Bay [Baker Bay] which lies in Latt. $46^{\circ} 20^{\prime}$ North Latitude. I advise your going over the bar into this bay on the flood tide, as the river Chinook [Columbia River] and two other considerable rivers empties themselves into this bay." ${ }^{40}$ 
Printed narratives of voyages and maps cast information more broadly. In 1789-1790, a few British fur traders published accounts and charts of their voyages. ${ }^{41}$ Nathaniel Portlock's $A$ Voyage round the World but more particularly to the North-West Coast of America, published in 1789, included six maps, but his accompanying "Chart of the North West Coast of America" that extended north of $56^{\circ}$ contained only ten place-names (none of them Native). In George Dixon's Voyage Round the World, published in 1789, his "Chart of the North West Coast of America” included only a few English common place-names. John Meares's Voyages Made in the Years 1788 and 1789, published late in 1790 , contained ten maps, seven covering the area from Cape Lookout to the Aleutian Islands. Those maps included many non-Native place-names as well as misleading information about a River of the West and the possibility of the circumnavigability of Vancouver Island. Meares's Voyages apparently was widely distributed, for in 1795, Captain Bishop, on the British ship Ruby, carried Meares's account and charts (along with Cook's) on his Northwest voyage. ${ }^{42}$

In London in 1790 and 1791, in a series of three pamphlets, Dixon and Meares engaged in acrimonious public debate over how each represented their voyages. ${ }^{43}$ The pamphlets publicized detailed geographic information to an audience that had become intensely aware of the geopolitical significance of the Northwest Coast because of the saber-rattling conflict with Spain during the 1789 Nootka Sound Controversy, when Spanish seizure of British fur-trading ships escalated tensions between the two countries vying for sovereignty rights in the Pacific Northwest. Portlock, Dixon, and Meares likely hoped to profit from their publications because of their associations with the East India Company, the South Sea Company, and government officials and perhaps because of their own notoriety. Portlock dedicated his work to the King of England, while Dixon inscribed his to Sir Joseph Banks, president of the Royal Society. By 1790, Meares had achieved prominence in London as a conveyor of direct observations of the events at Nootka Sound that had initiated the crisis. These publications were not available to Gray or Hoskins when they left Boston in September 1790, but Hoskins subsequently noted that he had become familiar with Dixon's "discovery" of the island group Dixon had christened "Queen Charlottes." 4

Importantly, during this period, American fur-trading voyages were not licensed under government regulations or given patronage as they were in England, and there was little or no connection between American geopolitics and private commercial enterprise on the Northwest Coast. This may be why no American fur traders published accounts of their voyages until 1798, when Ebenezer Johnson printed his "Short Account of a Northwest Voyage 
Performed in the Years 1796, 1797, \& 1798." ${ }^{45}$ Before 1798 in Britain, however, publications of commercial cartographers and the discourse between agents of the powerful East Indian Company and policy makers in government effectively communicated geographic details of explorations, which raised public consciousness about the Northwest Coast.

The East India and South Sea companies, chartered companies overseen by Parliament, tightly regulated private commercial ventures of British merchants operating on the coast as well as Chinese markets. Company regulations required returning ships' captains to turn over logs, records, and charts to company officials, who provided access to privileged interested parties. Foremost among the British cartographers who obtained this material was Aaron Arrowsmith, who was later named Hydrographer to the Prince of Wales and, subsequently, to the king. Arrowsmith was not the first English mapmaker to publish information from fur traders. ${ }^{46}$ But his keen interest in British maritime and transcontinental exploratory activities in North America led him to establish relationships with senior associates of major merchant monopolies in England - the East India Company, the North West Company, and the Hudson's Bay Company - giving him direct access to reports and cartographic material from the field. In April 1790, Arrowsmith published his first map, Chart of the World on Mercator's Projection, which incorporated geographic and place-name information from the voyages of six English fur traders - Dixon, Portlock, Meares, Charles Duncan, James Colnett, and William Douglas (Figure 7). He drew on Dixon's and Portlock's published accounts but likely obtained prepublication copies of Meares's and Douglas's narratives; and he had access to the unpublished accounts and charts of Colnett and Duncan, probably from direct communication with the East India Company hydrographer, Alexander Dalrymple. Almost all of Arrowsmith's place-names on the Northwest Coast originated from these accounts, and, unlike the toponymy on Hoskins's chart, his map gave no evidence of a Native presence; it was an authoritative construct of a solely British identity in the region. ${ }^{47}$

During the 1790s, Arrowsmith became Britain's most important geographer of exploration. By the beginning of the decade, he had established close associations with the British North West Company through Simon McTavish, one of its primary partners. On his 1790 map, for example, in a legend above the route of Alexander Mackenzie's 1789 trek to the Arctic, Arrowsmith credits McTavish for giving him access to Mackenzie's original journal. Arrowsmith produced this map during the Nootka Sound Controversy, a time when the British public was focused on the Pacific Northwest, thereby providing a ready reference for those interested. Also in 1790, the 


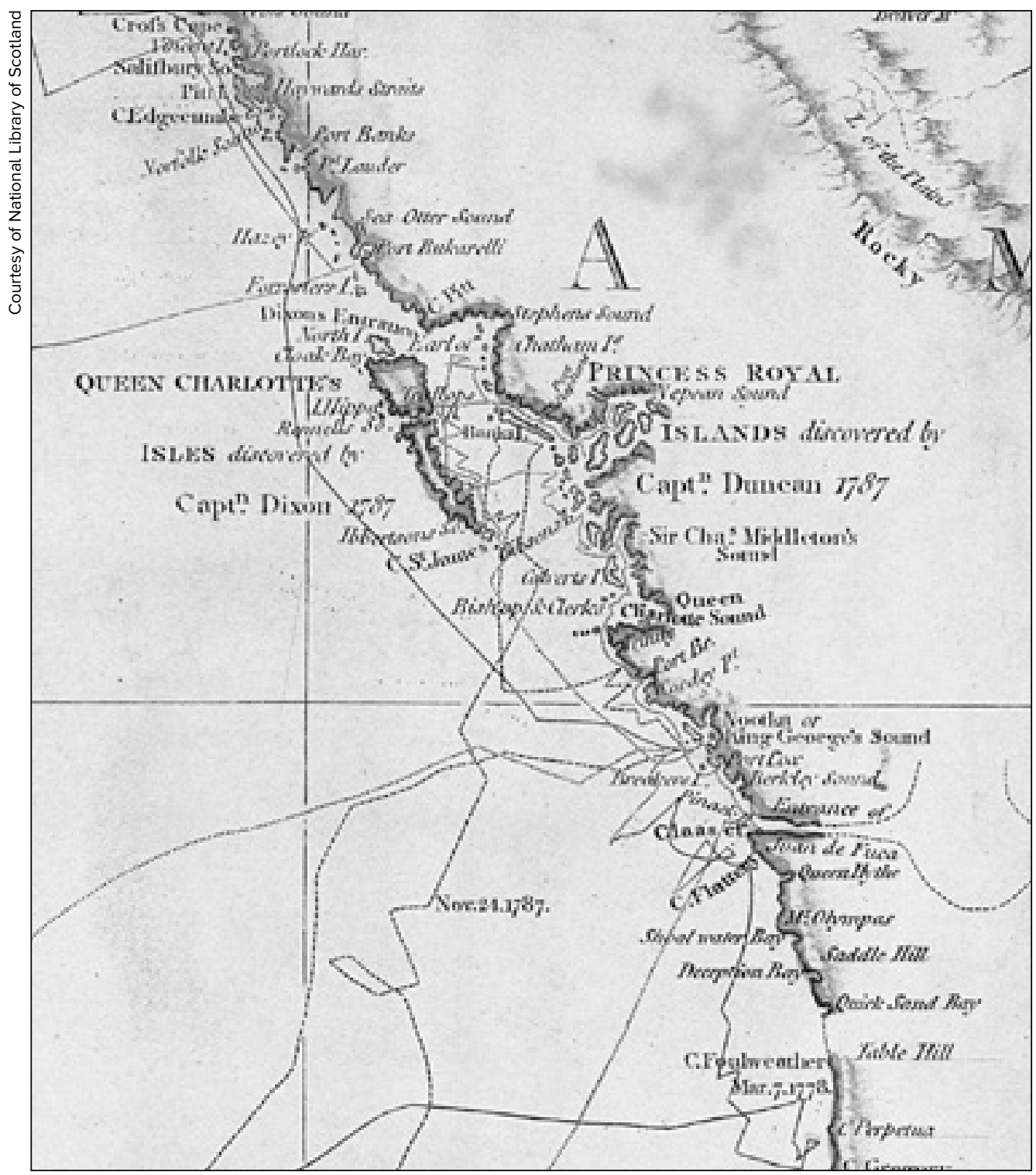

FIGURE 7: The Pacific Northwest section of Aaron Arrowsmith's 1790 "Chart of the World on Mercator's Projection...." Other cartographers copied this geographic and toponmy information, ensuring dissemination of Arrowsmith's reputation and the construct of a British identity of the region.

British foreign secretary, the Duke of Leeds, used Arrowsmith's map as part of his case for territorial sovereignty of Great Britain in the Pacific Northwest. ${ }^{48}$ And interestingly, Meares and Dixon, during their heated public exchange of letters in 1790 and 1791, referred to Arrowsmith's map as the most authorita- 
tive source of the geography of the Northwest Coast. Other cartographers, including Germans Georg Forster and Daniel Sotzmann (cartographer of the Royal Academy of Sciences in Berlin), copied Arrowsmith's cartography for their own maps, published in 1791, which helped establish Arrowsmith's international reputation and disseminate his geographical constructs. ${ }^{49}$

Arrowsmith was also responsible for illustrating the earliest information, before 1798, about Vancouver's exploration of the Strait of Juan de Fuca and the Columbia River. Vancouver surveyed Puget Sound in April and May 1792, and in October, Lt. William Broughton made a detailed survey of the Columbia River for approximately a hundred miles from its mouth. Vancouver did not return to London until late 1795, but he sent Broughton there in early 1793 with dispatches and copies of his charts. In January 1794, Arrowsmith published another world map on a different projection and dedicated it to Alexander Dalrymple, who had direct access to the logs, journals, and charts of ships licensed

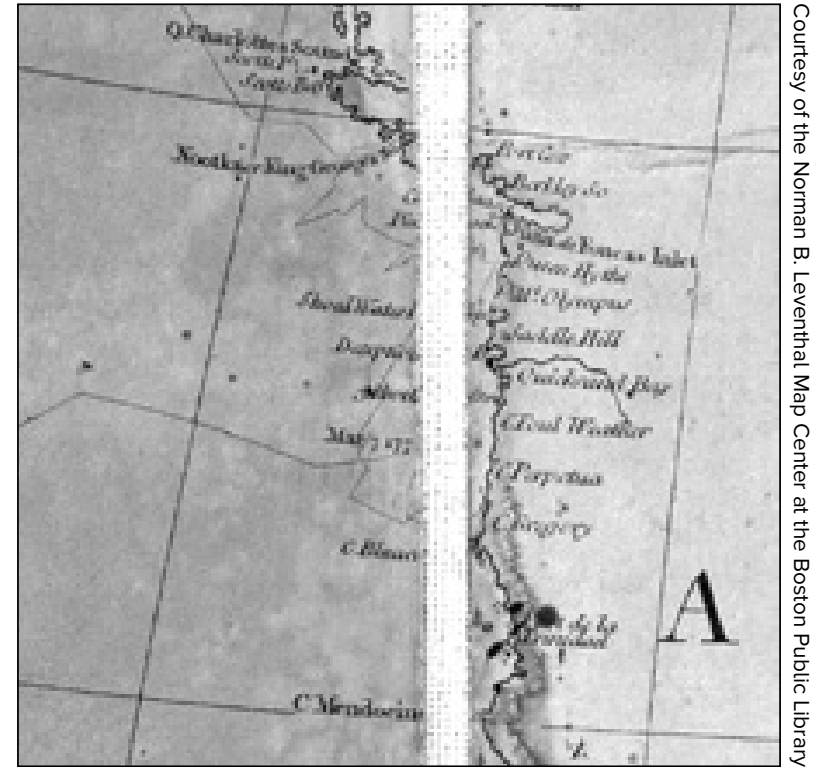

FIGURE 8: Section of Arrowsmith's 1794 world map with additional place names along the Washington and Oregon coast and the earliest printed illustration of the (unnamed) Columbia River. Break in the map as issued when linen backed sections were sewn together. by the East India Company to engage in the fur trade on the Northwest Coast. On this map, Arrowsmith incorporated two new significant pieces of information: he eliminated the dotted-line connection from the Entrance of Juan de Fuca to a hypothetical River Oregon, thus suggesting that the long-sought passage across the continent did not exist, and he added a segment of a river at approximately $46^{\circ}$ north latitude from Deception Bay (Figure 8). This as-yet-unnamed (by non-Natives) river was the first printed cartographic rendition and public record of the existence of what would become known as the Columbia River. Arrowsmith may have made both changes based on the accounts and charts that Vancouver had dispatched with Broughton to the Admiralty in July 1793, although it is puzzling that he did not depict evidence of Vancouver's explora- 


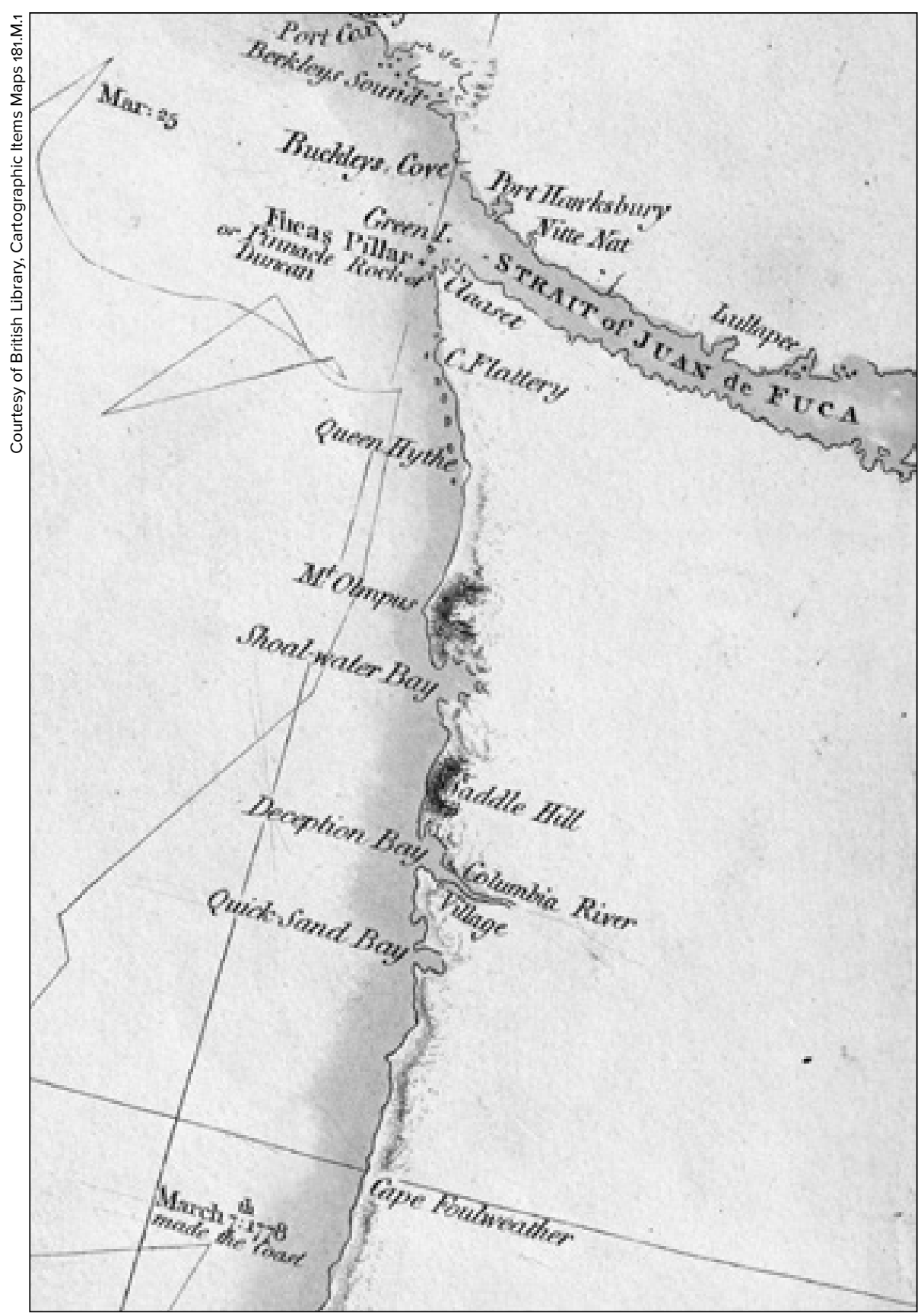

FIGURE 9: Detail of Arrowsmith's 1795 "A Map Exhibiting All the New Discoveries ..." For the first time on a printed map, Arrowsmith named the "Columbia River," but did not incorporate some of the most recent geographical information from Vancouver such as the presence of Puget Sound or Broughton's rendition of the Columbia River based on his survey. 
tion of Puget Sound. ${ }^{50}$ In January 1795, in the first edition of his celebrated $A$ Map Exhibiting All the New Discoveries in the Interior Parts of North America and for the first time on a printed map, Arrowsmith named the Columbia River near a Village on the southern shore (Figure 9). By 1802, he had revised this map and redrawn the Columbia River, re-naming it River Oregon, borrowing the changed topography but not the name from Vancouver's charts, which maintained the toponym Columbia River (Figure 10). ${ }^{51}$

Finally, the prolific output of pamphlets and maps of Dalrymple, British geographer and unofficial hydrographer to the East India Company, informed the public about early cartographic knowledge of the Northwest Coast. ${ }^{22}$ Beginning in 1789, Dalrymple published charts, plans, and surveys from the voyages of the company's captains, including the first maritime fur-trade venture on the Northwest Coast of British captain James Hanna, from 1785 to 1786.53 Through his membership in the Royal Society, Dalrymple developed close relationships with the intellectual and political elite of British society, including Joseph Banks, who shared an abiding interest in the geography and natural history of the Pacific Northwest. He also had access to the work of surveyors of the Hudson's Bay Company.

Dalrymple had a long interest in a navigable passage across the North American continent. In 1789, before the public was aware of the Nootka Sound Controversy, he publicly proposed a union between the East India Company and the Hudson's Bay Company, framed around the existence of a navigable river route between Hudson Bay and the Pacific Ocean. Dalrymple's 1789 Plan for Promoting the Fur Trade and Securing It to This Country by Uniting the Operations of the East-India and Hudson's Bay Companys was both commercial and imperial in intent. ${ }^{54}$ Connecting the fur trade in the interior and on the coast had the potential to generate both enormous profits and British imperial ascendency across the continent and in the North Pacific. The controversy at Nootka Sound made Dalrymple's geographic knowledge an imperial asset. "When diplomatic negotiations turned to territorial questions, the Foreign Office turned to Alexander Dalrymple," geographer Daniel Clayton wrote. He "was one of the principal custodians of geographical knowledge about North America and the Pacific." ${ }^{55}$ Commenting on geographical disputes such as the Nootka Sound Controversy, Dalrymple stridently argued for the primacy of maps. As he noted in his pamphlet The Spanish Pretensions Fairly Discussed in 1790, "the proper Authorities to consult are Geographers; for although a Map may not be considered as conclusive, it must be admitted as presumptive, testimony of fact." 56

The American maritime fur trade operated without an institutionalized cartographic establishment, commercial monopolies, or a geopolitical focus, all of which existed in England. By 1793, cartographic materials on much of 
the Northwest Coast, from Haida Gwaii to the Columbia River, obtained by American fur traders such as Ingraham, Haswell, Gray, Boit, and Hoskins, remained unpublished, the property of private interests. Ships' owners did not operate under the same licensing requirements as their British counterparts did, and public access to journals and charts was either limited by owners' proprietary concerns or considered irrelevant. During the late eighteenth century, American cartographers were more focused on publishing maps of the recently independent American Republic and individual states than on a distant part of the continent. Between 1790 and 1799, American publishers issued only sixteen maps of North America, and many of these were re-engravings from British cartographers. ${ }^{57}$ In January 1793, before the Columbia Rediviva returned to Boston, Secretary of State Thomas Jefferson, representing the American Philosophical Society, sent instructions to André Michaux for a proposed expedition of exploration to the Pacific Ocean. "It would seem by the latest maps as if a river called Oregon," Jefferson wrote, "interlocked with the Missouri for a considerable distance, and entered the Pacific ocean not far southward of Nootka Sound." ${ }^{8}$ Even ten years later, when he was planning the Lewis and Clark Expedition, President Jefferson apparently had no cartographic information about the Columbia River from the second voyage of the Columbia among his numerous cartographic references. ${ }^{59}$

The embryonic private and commercial American cartographic industry in Philadelphia, New York, and Boston relied almost entirely on published British maps for new geographic information on the American West and the Northwest Coast. In 1796, for example, John Reid in New York published "A General Map Of North America. Drawn From Best Surveys 1795" that closely copied information from Arrowsmith's 1794 map of the world, including the unnamed river stretching inland from Deception Bay. ${ }^{60}$ In 1799, Boston mathematician and surveyor Osgood Carleton drew the first American map that named the Columbia River. He copied the image directly from Vancouver's charts. ${ }^{61}$ As late as March 1803 , Secretary of the Treasury Albert Gallatin suggested to Jefferson that the principal reference maps of the American Northwest and West included those by Cook, Vancouver, and McKenzie, along with three maps by Arrowsmith. ${ }^{62}$

\section{HOSKINS'S MAP AND AMERICAN GEOPOLITICS}

The Pacific Northwest figured into the geopolitical calculations of Britain, Spain, Russia, and the United States during the late eighteenth and early nineteenth centuries, and cartography played an important role in each nation's ambition to control the region. The map of the Northwest Coast that 


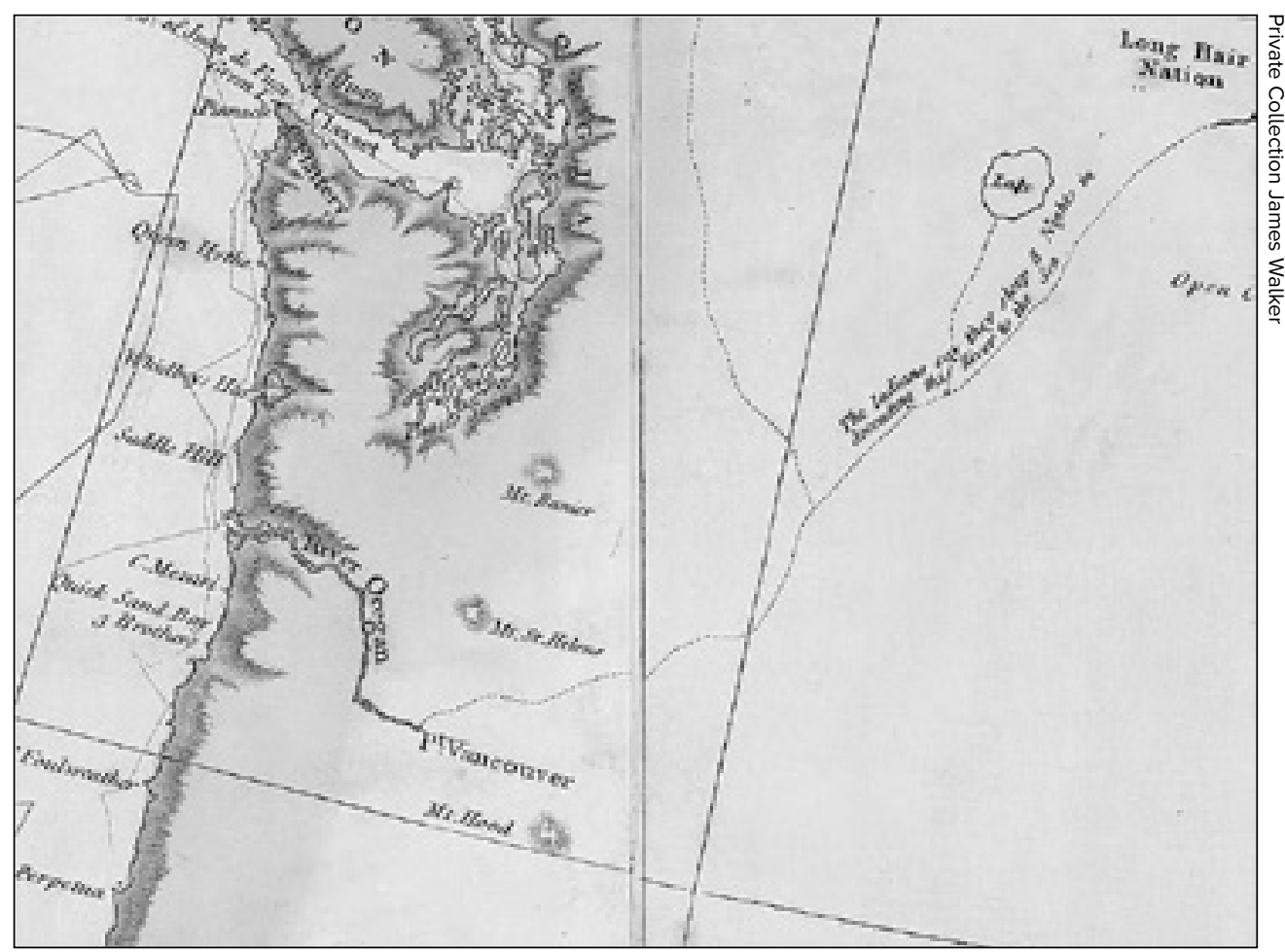

FIGURE 10: Detail of Arrowsmith's 1802 edition of "A Map Exhibiting All the New Discoveries ..." that included the most recent information from the 1798 publication of Vancouver's voyage.

Hoskins began sketching in 1791-1792 depicted a region where Britain and the United States made imperial claims. The two nations sorted out their territorial interests in the Pacific Northwest by 1846 , and while maps were important in the eventual resolution, Hoskins's map played no part. The map was in private hands and largely inaccessible to government officials, which arguably left American statesmen less prepared to advance their nation's cartographic perspectives in discussions with Great Britain about competing claims to the Pacific Northwest.

During the last fifteen years of the eighteenth century, the United States had not yet linked cartographic knowledge of the Northwest Coast with geopolitical and economic strategies for nation-building. It had no equivalent of an Alexander Dalyrmple, whose authority as a geographer in Parliament and intellectual circles in Britain ensured that knowledge from maps would be a powerful tool for the expansion of empire. In March 1793, for example, American trader John Kendrick had written to Jefferson that 
he had purchased five large tracts of land on Vancouver Island from Native chiefs in July and August 1791. He enclosed copies of his deeds and suggested that "the future commercial advantages which may arise from the fur trade. ... may perhaps render a settlement there, worthy of the attention of some associated company, under the protection of the government." ${ }^{6}$ The State Department received the letter on October 24, 1793, and Jefferson forwarded it to George Washington, but the president returned it without comment on November 2. News of that sort and cartographic evidence of such a claim would not have languished in the hands of British ministers. By the first decade of the nineteenth century, however, attitudes had changed in Washington, D.C.

Jefferson's administration purchased France's claim to the western Louisiana Territory in the spring of 1803 . Three years later, the president's Corps of Discovery, under the leadership of Meriwether Lewis and William Clark, returned from their overland exploratory journey to the Pacific Ocean. By 1811, John Jacob Astor had established Fort Astor at the mouth of the Columbia, focusing even more attention on the Pacific Northwest. Jefferson's successor, James Madison, pursued the geopolitical ramifications of the commercial maritime exploits of Gray, Astor, and others. Madison and Secretary of State James Monroe had an interest in Kendrick's reported land purchases and requested additional information. In 1816, at Madison's request, Boston architect Charles Bulfinch, one of the owners of the Columbia, extracted a portion of Gray's log book, which was in the possession of Silas Atkins, the brother of Gray's widow Martha. ${ }^{64}$ On February 7, 1817, Monroe wrote U.S. Judge John Davies of Massachusetts, asking for certification of the documents he had received from Bulfinch, "it being important to the interests of the U.S. to authenticate. ... the facts attending that voyage [of the Columbia], particularly so far as they relate to the discoveries made, and the purchases affected by Cap.' Kendricks from the Natives on that coast." ${ }^{\top} 5$ During a week-long tour of Boston in July 1817, Bulfinch shared additional materials, including "a journal of the vessel," with Monroe and Secretary of State John Quincy Adams. ${ }^{66}$

In early 1818 , on being appointed the Capitol architect of Washington, D.C., Bulfinch handed over to the president documents relating to the Northwest Coast. Most likely, the interest shown in these materials had to do with the post-War of 1812 diplomatic wrangling between the United States and Great Britain over possessory rights to the Pacific Northwest. American and British plenipotentiaries met in London in October 1818 and hashed out a treaty that relied on cartographic information from many British and American sources. We do not know if any of those documents included Hoskins's Narrative or his maps, but the negotiators used many detailed maps to demarcate a 
division of sovereignty between British and American territory in the Treaty of $1818 .{ }^{67}$ During several meetings of diplomats over the next several years, when the two nations continued to negotiate over the division of interests in the greater Pacific Northwest that resulted in the Oregon Treaty of 1846 , Hoskins's material did not appear as evidence.

While diplomats corresponded over claims to the Pacific Northwest, American politicians in Congress pursued their own interests in the region. A congressional committee called on Bulfinch's resources; and Benjamin Joy, Joseph Barrell's son-in-law, wrote Bulfinch on December 31, 1821, that he was "searching for Hoskins' journal, [and] I am informed by C. Barrell that you have it." 68 Joy wrote to Bulfinch as part of his response to a congressional request for such material from "Mr. Baylies or Mr. Floyd of a Committee on the N. West Coast." ${ }^{69}$ Virginia Congressman John Floyd was preparing to introduce the first bill to establish an Oregon Territory, and Congressman William Baylies's Select Committee was preparing an extensive two-part report to Congress on the history of British and American territorial claims to the territory of the Columbia River. ${ }^{70}$ Although Baylies's report quoted extensively from the accounts by Cook, Vancouver, Dixon, Gray, and other early explorers of the Columbia River, it included minimal information from other American fur traders, and Kendrick's land purchase warranted little more than a footnote. ${ }^{71}$ Because most material from fur-trading vessels was in private hands and generally inaccessible or because policy makers considered it less relevant, the kind of cartographic information that Hoskins laid on his map had no political impact.

Even though Hoskins and his remarkable map did not further American diplomatic or political interests in the Pacific Northwest or affect the outcome of contested sovereignty in the region, his cartography is much more than a historical curiosity. The Hoskins map is an orphan document, one that has been removed from its context, similar to taking an object out of its setting where it had obvious meaning and utility. Finding the map was serendipitous, and even its location in a Congressional committee file posed more questions than delivered answers. Still, the map offers a new window, however narrow, for us to imagine how Hoskins might have laid down the names he applied to the Northwest Coast depicted on his chart.

Before 1798, Hoskins's map would have contained new information valuable to many, and it was possessed by a Boston merchant who then knew something about geography and Native residency on the Northwest Coast that was absent from published maps. It is likely, however, that the Hoskins map had only a brief utility. The owners of the Columbia probably did not consider it more than a way-finding guide for future commercial voyages, but it was not long after the Columbia returned to Boston in 1793 that 
the ship's principal owner, Barrell, abandoned the fur trade for real estate speculation, which included the possible sale of the land purchases of his former employee, Kendrick. ${ }^{72}$ Hoskins's journal and maps probably passed to Bulfinch or Barrell at some point, becoming part of their large collection of ships' records. Joy specifically mentioned Hoskins's Narrative in his inquiry to Bulfinch in 1821, but the ship's owners would have seen Hoskins's map as unnecessary after the second and last voyage of the Columbia. After Vancouver's charts were published in 1798, navigators in the region would likely have seen Hoskins's map as nautically anachronistic. Drawn with profit in mind, Hoskins's map disappeared from view. It became a potentially valuable artifact in 1852, but for a different reason and for a different set of players, who sought congressional compensation for the accomplishments of their ancestors.

Today, because of the predominance in the modern cartographic literature of the published maps of Cook and Vancouver, the cartographic knowledge of maritime fur traders is less appreciated than it was before 1798. Hoskins's map, however, begs for appreciation, particularly because of his perceived geography of the coast and his detailed focus on Gray's contact with Native people, among the earliest encounters between fur traders and Indians on the Northwest Coast. Hoskins covered more coastal detail in relatively large scale of an area between $45^{\circ}$ and $55^{\circ}$ than other extant published or manuscript fur-trader maps of the era, and he was among the first to cartographically represent new, although imperfect, knowledge of the Columbia River and the insularity of Vancouver Island.

For modern readers, the value of Hoskins's map should be measured by the distinctive type of knowledge it contains. In the late eighteenth century - less than fifteen years after publication of Cook's charts in 1784 - maritime surveyors, commercial cartographers, policy makers, and fur traders produced or used maps that reflected different ways of perceiving the Pacific Northwest. We study their maps to appreciate and understand why they included or excluded information, how and why their representations appear to describe a wholly different place, and what they may have meant their maps to say. Publication of Vancouver's charts in 1798 made them the benchmark for navigation in the area. As one modern scholar noted, "the comprehensiveness of Vancouver's expedition and British maritime supremacy largely effaced earlier cartography and toponomy."73 But as Vancouver's maps illuminated coastal geography, they simultaneously effaced knowledge 
of a Native presence. Vancouver's maps created an imperial representation, a new and alternative identity for the region. Hoskins's map, devoid of details of ships' tracks, soundings, and surveying particulars, documents an extensive and diverse Native presence. It allows modern viewers to see beyond Vancouver's construction of imperial toponyms and deeply into an occupied land of cultures that today's scholars and many of the region's Native peoples continue to investigate, appreciate, and preserve. His meticulous chart did not play a role in trade economics, that we can determine, nor did it figure in diplomatic negotiations or political discussions and policy, or even public knowledge of the Northwest Coast in the early nineteenth century. His work, it appears, had no instrumental use. Yet, it would be a mistake to ignore its contents or its purposeful creation by John Box Hoskins, Columbia Rediviva supercargo. Hoskins constructed his chart to direct attention to places the Columbia and its crew had reached on the far Northwest Coast and what they knew about a region that contained great wealth in pelagic furs and likely many other valuable trade items. His map conveys an intimacy with the people on the Northwest Coast that expands our knowledge of the interaction between mariner trading groups and indigenous villages. The details of those interchanges are beyond our reach, but Hoskins offers a view that is not common among the map makers of his era - he privileges many specific places as Native locations, as reference points for future engagements. Although it is a sole representation of the Northwest Coast from the late eighteenth century, it prompts new questions about the full range of encounters that took place more than two centuries ago.

\section{NOTES}

The authors wish to thank Mr. Ralph Ehrenberg for initiating this research on Hoskins's map. For their generous assistance in facilitating our research, we acknowledge the staff of the University of Oregon Knight Library, the Oregon Historical Society Research Library, the Massachusetts Historical Society, the Library of Congress Manuscript Division, and the Cartographic and Architectural Section and Center for Legislative Archives at the
National Archives and Records Administration. Marianne Keddington-Lang provided much-appreciated editorial advice. Alethea Steingisser, Cartographic Projects Manager of the InfoGraphics Lab at the University of Oregon, supplied the images.

1. Little is known about Hoskins's early life. See Frederic W. Howay, ed., Voyages of the Columbia to the Northwest Coast 1787-1790 \& 1790-1793 (Portland: Oregon Historical Society 
Press in cooperation with The Massachusetts Historical Society, 1990), xx-xxii.

2. Joseph Barrell to John Hoskins, Boston, September 24, 1790, in Correspondence and Journals of Samuel Blachley Webb, volume 3, 1783-1806, ed. Worthington Chauncey Ford (New York: Wickersham Press, 1894), 167, found online at https://archive.org/stream/ corrjournalssamo3webbrich/corrjournalssamozwebbrich_djvu.txt (accessed March 7, 2017).

3. Howay, "John Hoskins's Narrative of the Second Voyage of the 'Columbia'," in Voyages of the Columbia, 161-289.

4. Ibid., 232.

5. Hoskins's map is located in RG 46, Senate Committees Maps (330/11/07/30) 33rd Congress, Senate Committee on Claims, Sess. $33 \mathrm{~A}-\mathrm{H} 2$, \#63 Maps accompanying claim of George Barrell, 4 items in 5 pieces at the Cartographic and Architectural Section of the National Archives and Records Administration [hereafter NARA] at College Park, Maryland, see http://research.archives.gov/description/4700279 (accessed March 7, 2017).

6. English papermaker James Whatman was responsible for producing many highquality papers from 1740-1794. By 1790, Whatman's son had incorporated this Strasburg shield watermark in paper that would have been available in the American northeast. See Thomas Balston, James Whatman Father \& Son (New York and London: Garland Publishing, Inc., 1979), 158-62.

7. For the published origins and the cartographic legacies of the apocryphal voyage of Admiral Bartholomew de Fonte, see Henry R. Wagner, The Cartography of the Northwest Coast of America to the Year 1800 (Amsterdam: N. Israel, 1968), 158-62. For the origin and cartographic legacy of the River of the West at $43^{\circ}$, see William L. Lang and James V. Walker, Explorers of the Maritime Pacific Northwest Mapping the World through Primary Documents (Santa Barbara, Calif.: ABC-CLIO/Greenwood, 2016), 15-19.

8. Wagner, Cartography of the Northwest Coast of America, 221-22; and Henry R. Wagner, Spanish Explorations in the Strait of Juan de Fuca (Mansfield Centre, Conn.: Martino Publishing, 2002), 15-25.

9. Wagner, Cartography of the Northwest Coast of America, 223-24; and Wagner, Spanish Explorations, 27-42.

10. Howay, "Robert Haswell's Log of the Second Voyage of the 'Columbia'," in Voyages of the Columbia, 353.

11. Howay, "John Boit's Log of the Second Voyage of the 'Columbia'," in Voyages of the Columbia, 405.

12. Paul Rigdon, Captain Robert Gray's Charts Discovered After Almost Two Centuries (Spokane, Wash.: Gonzaga University Press, 1975). For a detailed description of Gray's map, see Lang and Walker, Explorers of the Maritime Pacific Northwest, 249-52. Gray's map is also pictured in Derek Hayes, Historical Atlas of Washington and Oregon (Berkeley: University of California Press, 2011), 25, and in J. Richard Nokes, Columbia's River: The Voyages of Robert Gray, 1787-1793 (Tacoma: Washington State Historical Society, 1991), 192.

13. The four names of uncertain origin include Savage Cove on the east side of Vancouver's Island, Old Man's Bluff, Boat Cove, and Beef Inlet along the current Oregon coast.

14. Many ships' captains carried copies of James Cook's chart of the Pacific Northwest published in 1784. Among the very few published accounts of commercial maritime voyages were those of Dixon in 1789 and Meares in 1790. Hoskins does not mention either of these accounts when he left Boston in September 1790, but he would have had access to them after his return nearly three years later.

15. The four names that are not decipherable are Quahik and Ohcot[?]hlet along the west coast of Vancouver Island; Enina[?] and Kotah located in Gray's Harbor.

16. Howay, "John Hoskins's Narrative," in Voyages of the Columbia, 235-36.

17. Wagner, Cartography of the Northwest Coast of America, 184.

18. Quoted from His Honour Judge F. W. Howay, LLD., ed., The Journal of Captain James Colnett Aboard the Argonaut from April 26, 1789 to Nov. 3, 1791 (Toronto: The Champlain Society, 1940), 33, 36. For additional 
discussion of Meares's orders, see Lang and Walker, Explorers of the Maritime Pacific Northwest, 125-27.

19. James R. Gibson, Otter Skins, Boston Ships, and China Goods (Seattle: University of Washington Press, 1999), 299-300; Judge F.W. Howay, "A List of Trading Vessels in Maritime Fur Trade, 1785-1794," The Transactions of the Royal Society of Canada Section 2 (1930): 111-34. For a detailed description of vessels of the American maritime fur trade with bibliographic citations, see Mary Malloy, "Boston Men" on the Northwest Coast: The American Maritime Fur Trade 1788-1844 (Kingston and Fairbanks: Limestone Press and University of Alaska Press, 1998).

20. Daniel W. Clayton, Islands of Truth: The Imperial Fashioning of Vancouver Island (Vancouver: UBC Press, 2000), 82-84.

21. Alexander Walker, An Account of a Voyage to the North West Coast of America in 1785 \& 1786, ed. Robin Fisher and J.M. Bumsted (Vancouver: Douglas and Mclntyre and Seattle: University of Washington Press, 1982), $226 n 68$.

22. Nokes, Columbia's River The Voyages of Robert Gray, 330n15.

23. Howay, "John Hoskins' Narrative," in Voyages of the Columbia, 176, 280.

24. Ingraham's Journal of the Voyage of the Brigantine "Hope" from Boston to the North-West Coast of America is located in the Manuscript Division, Library of Congress, Washington, D.C., and can be accessed online https://www.wdl.org/en/item/436/ (accessed March 7, 2017). See also Mark D. Kaplanoff, ed., Joseph Ingraham's Journal of the Brigantine HOPE on a Voyage To The Northwest Coast of North America 1790-92 (Barre, Massachusetts: Imprint Society, 1971). Several of Ingraham's maps are illustrated in Derek Hayes, Historical Atlas of the Pacific Northwest: Maps of Exploration and Discovery, British Columbia, Washington, Oregon, Alaska, Yukon (Seattle: Sasquatch Books, 1999), 83-84.

25. Howay, "Robert Haswell's Log of the Second Voyage," in Voyages of the Columbia, 336, 345; additional harbor maps are included in Haswell's manuscript narrative located at the Massachusetts Historical Society, P-369, 1 reel (microfilm).

26. Nokes, Columbia's River The Voyages of Robert Gray, $317 n 15$.

27. Robert Haswell to Joseph Barrell, August 5, 1801, Columbia Rediviva (Ship) MSS 957, Oregon Historical Society Research Library, Portland, Oregon [hereafter OHS Research Library].

28. Captain John Boit to Charles Bulfinch, April 1, 1820, John Kendrick letters, 1787-1845, MSS 152, OHS Research Library.

29. The longstanding and complicated diplomatic negotiations between the United States and England that culminated in the Oregon Treaty of 1846 are examined in detail by Fredrick Merk, The Oregon Question Essays in Anglo-American Diplomacy \& Politics (Cambridge, Mass.: The Belknap Press of Harvard University Press, 1967).

30. Journal of the House of Representatives of the United States, 1839-1840, Memorial of Charles Bulfinch, ET AL, 26th Cong., 1st sess., Doc. No. 43, January 13, 1840.

31. Journal of the House of Representatives of the United States, Memorial of Martha Gray, of Boston, 29th Cong., 1st sess., Doc. No. 172, March 27, 1846.

32. Journal of the Senate of the United States of America, Memorial of Charles [sic.] Barrell, 31st Cong., 1st sess., February 15, 1850.

33. Senate Committee on Public Lands, Memorial of George Barrell, 32nd. Cong., 1st sess., Rep. Com. No. 335, August 11, 1852. For a brief summary of Congressional committee action on the petitions of Martha Gray and others, see Nokes, Columbia's River The Voyages of Robert Gray, 276-78.

34. Personal communication, Betty K. Koed, Associate Historian, Unites States Senate, to author, March 4, 2015.

35.Petition George Barrell and S.V.S. Wilder, Heirs of Jno. Kendrick and the Heirs of CapT. Rob.T. Gray, Center for Legislative Archives, National Archives and Records Administration, RG 46, 33rd Cong. Senate Committee on Claims, Box 55 for SEN 33A-H2.

36. Haswell's and Boit's journals relate extremely cordial relationships with Bodega, 
although neither author specifically mentions sharing a chart of the Columbia River with the Spanish commandant. Most historians assume this exchange did occur. See Thomas Bulfinch, Oregon and Eldorado; or, Romance of the Rivers (Boston: J.E. Tilton and Co., 1866), 11. Haswell specifically states that Gray and Vancouver exchanged cartographic information; however, see Howay, "Haswell's Log," Voyages of the Columbia, 353.

37. Papers of Joseph Ingraham, 17901792: Journal of the Voyage of the Brigitine "Hope" from Boston to the North-West Coast of America located in the Manuscript Division, Library of Congress and is available online at, http://www.wdl.org/en/item/436 (accessed March 7, 2017). Book 4, 206, is Ingraham's acknowledgment of Gray as source of information for his map.

38. Edmond Hayes, ed., Log of The Union John Boit's Remarkable Voyage To the Northwest Coast and Around the World (Portland: Oregon Historical Society Press, 1981), 55.

39. Bernard Magee's Log of the Jefferson, Massachusetts Historical Society, September 7, 1793, Bernard Magee Logbooks, 1790-1794 $\mathrm{N}-126$, microfilm, Reel 1.

40. T.C. Elliott, “Journal of Captain Charles Bishop of the Ruby in 1795," Oregon Historical Quarterly 29:4 (December 1928): 340.

41. Wagner, Cartography of the Northwest Coast of America, 206-213. For excellent images of several of these maps, see Hayes, Historical Atlas of the Pacific Northwest, 58-62.

42. T.C. Elliott, "Journal of Captain Charles Bishop," 342.

43. Frederic W. Howay, ed., The DixonMeares Controversy (New York: Da Capo Press, 1969).

44. Howay, “John Hoskins' Narrative," in Voyages of the Columbia, 232.

45. Malloy, "Boston Men," 112-13.

46. Wagner, Cartography of the Northwest Coast of America, 352, No. 736 notes an earlier map drawn by English cartographer Samuel Dunn in 1789.

47. Lang and Walker, Explorers of the Maritime Pacific Northwest, 138-41.

48. Clayton, Islands of Truth, 179.
49. These maps appeared in Geschichte der Reisen, die seit Cook an der Nordwestund Nordost-Küste von Amerika und in dem nördlichen Amerika selbst von Meares, Dixon, Portlock, Coxe, Long," published in Berlin in 1792. Forster sailed on James Cook's Second Voyage. His large scale map of the Pacific Northwest coast of America incorporates much of the geography and typonomy from Arrowsmith's 1790 world map, and the title cites the sources of the map content as "Hanna, Johnstone, Wedgborough, Portlock, Dixon, Duncan, Meares and de la Quadra."

50. Arrowsmith reissued this map in 1799 , 1808, and 1814. See Henry Stevens and Roland Tree, "Comparative Cartography" in R.V. Tooley, The Mapping of America (London: Holland Press Limited, 1980), 107. On the 1799 version, Arrowsmith illustrated Puget's Sound and the Columbia River based on the 1798 published charts of George Vancouver.

51. The shape of the river, named features (Pt. Vancouver, Mt. Ranier, and so on), and depiction of the (unnamed) Puget's Sound all derive from Vancouver's charts. One can only speculate, however, why Arrowsmith changed the name from Vancouver's "Columbia River" to "River Oregon."

52. The most comprehensive account of Dalrymple's life and prolific cartographic output is Andrew S. Cook, Alexander Dalrymple (1737-1808), Hydrographer to The East India Company And To The Admiralty As Publisher: A Catalogue Of Books And Charts (Ph.D. diss., University of St. Andrews, 1993), http://hdl.handle.net/10023/2634 (accessed March 7, 2017).

53. Ibid; many of these maps are listed in Wagner, Cartography of the Northwest Coast of America, 213, 350-53, 356.

54. Alexander Dalrymple, Plan for Promoting the Fur-Trade, Securing It to This Country, by Uniting the Operations of the East-India and Hudson's-Bay Companys by Dalrymple (London: Printed by George Bigg, 1789).

55. Clayton, Islands of Truth, 179.

56. Ibid, italics in original.

57. See, for example, James Clements Wheat and Christian F. Brun, Maps and 
Charts Published in America Before 1800 A Bibliography, Revised Edition Holland Press Cartographica 3 (London: The Holland Press Limited, 1978).

58. A.P. Nasatir, ed., Before Lewis and Clark Documents Illustrating the History of the Missouri 1785-1804, vol. 1 (Lincoln and London: University of Nebraska Press, 1990, Volume 1), 165.

59. John Logan Allen, Passage Through the Garden Lewis and Clark and the Image of the American Northwest (Urbana, Chicago, and London: University of Illinois Press, 1975), 59-70. For the maps consulted by Thomas Jefferson, see Stephen Dow Beckham, et al., The Literature of The Lewis and Clark Expedition: A Bibliography and Essays (Portland, Ore.: Lewis \& Clark College, 2003), 59-70.

6o. Wheat and Brun, Maps and Charts Published in America Before 1800: A Bibliography (London: Holland Press, 1978), 10. This map is illustrated in The David Rumsey Historical Map Collection, http://www.davidrumsey.com/luna/ servlet/detail/RUMSEY 8 $^{\sim}{ }^{\sim} 160^{\sim}$ 20005:Mapof-North-America-?sort=Pub_List_No_ InitialSort\%2CPub_Date\%2CPub_List_ No\%2CSeries_No?\&qvq=q:reid;sort:Pub_ List_No_Initialsort\%2 CPub_ Date\%2CPub_List_No\%2CSeries_ No;lc:RUMSEY ${ }^{\sim} \sim 1 \& \mathrm{mi}=6 \&$ trs $=77$ (accessed March 7, 2017).

61. Wheat and Brun, Maps and Charts, 11. This map is illustrated in the Map Collection of the John Carter Brown Library http:// jcb.lunaimaging.com/luna/servlet/detail/ JCBMAPS ${ }^{\sim}{ }^{\sim} 1^{\sim} 3778^{\sim}$ 101916:A-new-chart-ofthe-N--W--coast-of-A?qvq=q:osgood\%2Bcarl eton;lc:JCB ${ }^{\sim}{ }^{\sim} 1, \mathrm{JCBBOOKS}{ }^{\sim} \sim 1, J C B M A P S^{\sim}{ }^{\sim}$ $1, \mathrm{JCBMAPS}{ }^{\sim} 2^{\sim} 2, \mathrm{JCBMAPS}^{\sim} 3^{\sim} 3 \& \mathrm{mi}=7 \& \operatorname{trs}=10$ (accessed March 7, 2017).

62. See Gallatin's letter to Jefferson, quoted in Allen, Passage Through the Garden, 74. Gallatin did not identify the "three maps of Arrowsmith," but one would most likely have been the first 1802 edition of "A Map Exhibiting All the New Discoveries in the Interior Parts of North America" described above.

63. Letter to Thomas Jefferson from John Kendrick, Port Independence, on the Island of Hong Kong, March 1, 1793, in Senate Committee on Public Lands, Memorial of George Barrell, 32nd. Cong., 1st sess., Rep. Com. No. 335. August 11, 1852, 19.

64. Robert Greenhow, The History of Oregon and California and the Other Territories of the North-West Coast of North America (Boston: Charles C. Little and James Brown, 1844), 434; Edmond S. Meany, "The Widow of Captain Robert Gray," Washington Historical Quarterly 20 (July, 1929): 192-95.

65. Letter, James Monroe to Hon. John Davies, February 7, 1817, in RG 46, 33rd Cong. Senate Committee on Claims, Sess $33 \mathrm{~A}-\mathrm{H}_{2}$, \#63, second of four folders at Legislative Branch of NARA.

66. For reference to this exchange in Boston, see letter from John Quincy Adams to Charles Bulfinch, Washington, December 1, 1817, reprinted in Nokes, Columbia's River The Voyages of Robert Gray, 294.

67. Clayton, Islands of Truth, 205-223; Merk, Oregon Question, 46-71.

68. Benjamin Joy to Charles Bulfinch, December 31, 1821, Center for Legislative Archives, National Archives and Records Administration, RG 46, 33rd Cong. Senate Committee on Claims, Sess $33 \mathrm{~A}-\mathrm{H}_{2}$, \#63, folder 2.

69. Ibid.

70. For a discussion of the congressional and cartographic context of this period, see James V. Walker, "Henry S. Tanner and Cartographic Expression of American Expansionism in the 1820s," Oregon Historical Quarterly 111:4 (Winter 2010): 416-43.

71. House of Representatives, Select Committee Report on Exploration of the Northwest Coast, 19th. Cong, 1st sess., January 16, 1826, Rep. No. 35; and Northwest Coast of America, 19th Cong., 1st sess., May 15, 1826, Rep. No. 213.

72. John Scofield, Hail, Columbia Robert Gray, John Kendrick and the Pacific Fur Trade (Portland: Oregon Historical Society Press, 1993), 315.

73. Robert Galois, ed., A Voyage to the North West Side of America: The Journals of James Colnett, 1786-89 (Vancouver: UBC Press, 2004), 29. 